NBER WORKING PAPER SERIES

\title{
CHAINS OF OWNERSHIP, REGIONAL TAX COMPETITION, AND FOREIGN DIRECT INVESTMENT
}

\author{
Mihir A. Desai \\ C. Fritz Foley \\ James R. Hines Jr. \\ Working Paper 9224 \\ http://www.nber.org/papers/w9224 \\ NATIONAL BUREAU OF ECONOMIC RESEARCH \\ 1050 Massachusetts Avenue \\ Cambridge, MA 02138 \\ September 2002
}

The authors thank Edward M. Graham, Robert Lipsey, and various seminar participants for helpful comments on earlier drafts. The statistical analysis of firm-level data on U.S. multinational companies was conducted at the International Investment Division, Bureau of Economic Analysis, U.S. Department of Commerce under arrangements that maintain legal confidentiality requirements. The views expressed are those of the authors and do not reflect official positions of the U.S. Department of Commerce. Financial support from the Lois and Bruce Zenkel Research Fund at the University of Michigan and the Division of Research at Harvard Business School is gratefully acknowledged. The views expressed herein are those of the authors and not necessarily those of the National Bureau of Economic Research.

(C) 2002 by Mihir A. Desai, C. Fritz Foley and James R. Hines Jr.. All rights reserved. Short sections of text, not to exceed two paragraphs, may be quoted without explicit permission provided that full credit, including (C) notice, is given to the source. 
Chains of Ownership, Regional Tax Competition, and Foreign Direct Investment

Mihir A. Desai, C. Fritz Foley, and James R. Hines Jr.

NBER Working Paper No. 9224

September 2002

JEL No. H87, H25, F36, F23, F21, G32

\begin{abstract}
$\underline{\text { ABSTRACT }}$
This paper considers the effect of taxation on the location of foreign direct investment (FDI) and taxable income reported by multinational firms with particular attention to the regional dynamics of tax competition and the role of chains of ownership. Confidential affiliate-level data are used to compare the investment and income-reporting behavior of American-owned foreign affiliates across ownership forms and regions. Ten percent higher tax rates are associated with 5.0 percent lower FDI, controlling for parent company and observable aspects of local economies, and 0.9 percent lower returns on assets, controlling for parent company and level of FDI. Tax effects are particularly strong within Europe, where ten percent higher tax rates are associated with 7.7 percent lower FDI and 1.7 percent lower returns on assets. Indirectly owned foreign affiliates also exhibit strong tax effects, ten percent higher tax rates being associated with 12.0 percent lower FDI and 1.4 percent lower returns on assets. American firms finance a growing fraction of their foreign operations indirectly through chains of ownership, which now account for more than 30 percent of aggregate foreign assets and sales. Ownership chains are particularly concentrated among European affiliates. Since multinational firms from countries other than the United States face tax environments similar to those faced by indirectly owned affiliates of American companies, these results suggest a greater sensitivity of FDI to taxes for non-American firms. The results also suggest that European economic integration may have the effect of intensifying tax competition between European jurisdictions.
\end{abstract}

Mihir A. Desai
Harvard Business School
Morgan 363
Soldiers Field
Boston, MA 02163
mdesai@hbs.edu

Mihir A. Desai

(@)hbs.edu

\author{
C. Fritz Foley \\ University of Michigan \\ Business School \\ 701 Tappan Street \\ Ann Arbor, MI 48109-1234 \\ ffoley@umich.edu
}

James R. Hines Jr.

University of Michigan

Business School

701 Tappan Street

Ann Arbor, MI 48109-1234

jrhines@umich.edu 


\section{Introduction}

It is an article of faith - among politicians as well as scholars - that government policies have the potential to influence the extent and nature of economic activity, particularly when policies impede the normal functioning of business. Examples include regulatory regimes that discourage business formation, legal systems and institutions that make it difficult to execute and enforce commercial contracts, and tax systems that impose excessive burdens on incomeproducing activities. The desire of most governments to attract foreign direct investment (FDI) directs special attention to the way in which policies affect the location and activities of multinational firms.

The purpose of this paper is to consider the impact of taxation on FDI, emphasizing the effects of tax differences within regions (Europe in particular), and the behavior of FDI financed through chains of ownership. The effect of taxation on FDI has received considerable prior attention in the economics literature, where there is an emerging consensus that taxation strongly influences both the volume of FDI and the operational behavior of multinational firms. The evidence suggests that high tax rates discourage FDI not only by depressing after-tax investment returns but also by changing the opportunities available to firms that have discretion in reporting the location of taxable income.

Much of the prior research on the impact of taxation on FDI draws conclusions based on the behavior of American multinational firms. This tendency, which reflects the ready availability of data on American companies, implicitly emphasizes the incentives created by the U.S. tax system. Since the U.S. tax system differs in important respects from tax systems in many other countries, it is possible that the effects of taxation on non-American investors differ from those established in the literature. In particular, the foreign tax credit system used by the United States is likely to make American investors less sensitive to tax rate differences than are investors from many other countries.

This paper follows much of the literature in analyzing the behavior of American companies, though its purpose is to measure the extent to which tax effects change when affiliates avoid some of the effects of the U.S. tax system and when affiliates face intensified tax competition within the European Union. In order to estimate the effects of U.S. ownership, it is 
instructive to consider FDI undertaken through chains of ownership by American companies. In principle, the income earned by these indirectly owned affiliates is subject to taxation by the United States on the same basis as is any foreign income - while in practice, indirect ownership typically provides a layer of tax removal that creates incentives similar to those faced by investors from countries other than the United States. The evidence, drawn from confidential affiliate-level data on the behavior of American companies between 1982-1997, indicates that the investment pattern of indirectly owned affiliates is considerably more sensitive to local tax rates than is the investment pattern of directly owned foreign affiliates. Given the parallel between the tax incentives created by chains of ownership and the exemption rules employed by many countries other than the United States, these results suggest a greater sensitivity of FDI to taxes for nonAmerican firms.

The affiliate-level data employed in this paper allows for the use of various fixed effects in estimating the impact of tax differences. Tax effects then reflect the distribution of investment and activity between affiliates of the same company or between affiliates within the same industry that happen to be located in countries with differing tax rates. The advantage of using such a method is that doing so implicitly controls for any attributes, including differences in financial health that are common to affiliates of the same parent or to affiliates in the same industry. The regressions presented in Tables 5-8 indicate that controls for fixed effects significantly increase the estimated magnitudes of relevant tax effects.

An important goal of European economic integration has been to reduce barriers to the flow of economic activity within Europe. Tax initiatives have attempted to mitigate the extent to which tax differences dictate resource allocation within Europe, with the idea that European taxation should be directed at financing the public sector with as little as possible associated economic distortion. The evidence indicates that American companies are considerably more sensitive to tax rate differences within Europe (and within Latin America) than they are to tax rate differences between other countries. This behavior suggests that the similarity of European economies and strong efforts to create a single market within Europe may serve to intensify rather than mitigate pressures for tax competition. Additionally, the ability of firms to use indirect ownership within Europe appears to amplify their sensitivity to local tax incentives. The 
combination of world economic integration and the mobility of FDI suggests that tax competition is likely to intensify in the future.

Section two of the paper surveys the rules that govern the taxation of multinational firms, reviews the literature evaluating the effect of taxation on FDI and other aspects of the activity of multinational firms, and considers the differential incentives created by the possibility of chains of ownership. Section three presents a model of multinational behavior, and describes the data used in the empirical analysis that follows. Section four presents the empirical results, and considers their implications. Section five is the conclusion.

\section{International taxation in perspective ${ }^{l}$}

It is useful to review systems of taxing international income order to interpret the incentives facing American firms investing in foreign locations. The focus of this review is on American firms since they are the subject of the empirical analysis to follow. This summary of international tax rules provides not only a basis for the analysis that follows in sections 3 and 4, but also serves as a framework with which to interpret the studies reviewed in section 2.2. Finally, section 2.3 on chains of ownership further motivates the focus on indirect ownership in the empirical work that follows.

\subsection{International tax practice}

The taxation of international transactions differs from the taxation of domestic economic activity primarily due to the complications that stem from the taxation of the same income by multiple governments. In the absence of double tax relief, the implications of multiple taxation are potentially quite severe, since national tax rates are high enough to eliminate, or at least greatly discourage, most international business activity if applied two or more times to the same income.

\subsubsection{The foreign tax credit}

Almost all countries tax income generated by economic activity that takes place within their borders. In addition, many countries - including the United States - tax the foreign incomes

\footnotetext{
${ }^{1}$ Some parts of this brief description of international tax rules and evidence of behavioral responses to international taxation are excerpted from Hines (1991, 1997, 1999) and Hines and Hubbard (1995).
} 
of their residents. In order to prevent double taxation of the foreign income of Americans, U.S. law permits taxpayers to claim foreign tax credits for income taxes (and related taxes) paid to foreign governments. ${ }^{2}$ These foreign tax credits are used to offset U.S. tax liabilities that would otherwise be due on foreign-source income. The U.S. corporate tax rate is currently 35 percent, so an American corporation that earns $\$ 100$ in a foreign country with a 10 percent tax rate pays taxes of $\$ 10$ to the foreign government and $\$ 25$ to the U.S. government, since its U.S. corporate tax liability of $\$ 35$ (35 percent of $\$ 100$ ) is reduced to $\$ 25$ by the foreign tax credit of $\$ 10$.

\subsubsection{Tax deferral}

Americans are permitted to defer any U.S. tax liabilities on certain unrepatriated foreign profits until they receive such profits in the form of dividends. ${ }^{3}$ This deferral is available only on the active business profits of American-owned foreign affiliates that are separately incorporated as subsidiaries in foreign countries. The profits of unincorporated foreign businesses, such as those of American-owned branch banks in other countries, are taxed immediately by the United States.

To illustrate deferral, consider the case of a subsidiary of an American company that earns $\$ 500$ in a foreign country with a 20 percent tax rate. This subsidiary pays taxes of $\$ 100$ to the foreign country (20 percent of \$500), and might remit \$100 in dividends to its parent U.S. company, using the remaining $\$ 300$ (\$500 - \$100 of taxes - $\$ 100$ of dividends) to reinvest in its own, foreign, operations. The American parent firm must then pay U.S. taxes on the $\$ 100$ of dividends it receives (and is eligible to claim a foreign tax credit for the foreign income taxes its subsidiary paid on the \$100). ${ }^{4}$ But the American firm is not required to pay U.S. taxes on any part of the $\$ 300$ that the subsidiary earns abroad and does not remit to its parent company. If, however, the subsidiary were to pay a dividend of $\$ 300$ the following year, the firm would then be required to pay U.S. tax (after proper allowance for foreign tax credits) on that amount.

\footnotetext{
${ }^{2}$ The United States is not alone in taxing the worldwide income of its residents while permitting them to claim foreign tax credits. Other countries with such systems include Greece, Italy, Japan, Norway, and the United Kingdom. Under U.S. law, taxpayers may claim foreign tax credits for taxes paid by foreign firms of which they own at least 10 percent, and only those taxes that qualify as income taxes are creditable.

${ }^{3}$ Deferral of home-country taxation of the unrepatriated profits of foreign subsidiaries is a common feature of systems that tax foreign incomes. Other countries that permit this kind of deferral include Canada, Denmark, France, Germany, Japan, Norway, Pakistan, and the United Kingdom.

${ }^{4}$ In this example, the parent firm is eligible to claim a foreign tax credit of $\$ 25$, representing the product of foreign taxes paid by its subsidiary and the subsidiary's ratio of dividends to after-tax profits [ $\$ 100 \times(\$ 100 / \$ 400)=\$ 25]$.
} 
U.S. tax law contains provisions designed to prevent American firms from delaying the repatriation of lightly-taxed foreign earnings. These tax provisions apply to controlled foreign corporations, which are foreign corporations owned at least 50 percent by American individuals or corporations who hold stakes of at least 10 percent each. Under the Subpart F provisions of U.S. law, some foreign income of controlled foreign corporations is "deemed distributed," and therefore immediately taxable by the United States, even if not repatriated as dividend payments to American parent firms. ${ }^{5}$

\subsubsection{Excess foreign tax credits}

Since the foreign tax credit is intended to alleviate international double taxation, and not to reduce U.S. tax liabilities on profits earned within the United States, the foreign tax credit is limited to U.S. tax liability on foreign-source income. For example, an American firm with \$200 of foreign income that faces a U.S. tax rate of 35 percent has a foreign tax credit limit of $\$ 70$ (35 percent of \$200). If the firm pays foreign income taxes of less than $\$ 70$, then the firm would be entitled to claim foreign tax credits for all of its foreign taxes paid. If, however, the firm pays $\$ 90$ of foreign taxes, then it would be permitted to claim no more than $\$ 70$ of foreign tax credits.

Taxpayers whose foreign tax payments exceed the foreign tax credit limit are said to have "excess foreign tax credits;" the excess foreign tax credits represent the portion of their foreign tax payments that exceed the U.S. tax liabilities generated by their foreign incomes. Taxpayers whose foreign tax payments are smaller than their foreign tax credit limits are said to have "deficit foreign tax credits." American law permits taxpayers to use excess foreign tax credits in one year to reduce their U.S. tax obligations on foreign source income in either of the two previous years or in any of the following five years.

In practice, the calculation of the foreign tax credit limit entails certain additional complications, notable among which is that total worldwide foreign income is used to calculate the

\footnotetext{
${ }^{5}$ Subpart $\mathrm{F}$ income consists of income from passive investments (such as interest and dividends received from investments in securities), foreign base company income (that arises from using a foreign affiliate as a conduit for certain types of international transactions), income that is invested in United States property, money used offshore to insure risks in the United States, and money used to pay bribes to foreign government officials. American firms with foreign subsidiaries that earn profits through most types of active business operations, and that subsequently reinvest those profits in active lines of business, are not subject to the Subpart F rules, and are therefore able to defer U.S. tax liability on their foreign profits until they choose to remit dividends at a later date.
} 
foreign tax credit limit. This method of calculating the foreign tax credit limit is known as "worldwide averaging." A taxpayer has excess foreign tax credits if the sum of worldwide foreign income tax payments exceeds this limit.

\subsection{Empirical lessons from international taxation}

International tax rules and the tax laws of other countries have the potential to influence a wide range of corporate and individual behavior, including, most directly, the location and scope of international business activity. A sizable literature is devoted to measuring behavioral responses to international tax rules. ${ }^{6}$ This literature focuses on the impact of corporate tax rates on investment behavior as well as various financial and organizational practices used to avoid taxes.

\subsubsection{Investment}

Tax policies are obviously capable of affecting the volume and location of FDI, ${ }^{7}$ since, all other considerations equal, higher tax rates reduce after-tax returns, thereby reducing incentives to commit investment funds. Of course, all other considerations are seldom equal. Countries differ not only in their tax policies, but also in their commercial and regulatory policies, the characteristics of their labor markets, the nature of competition in product markets, the cost and local availability of intermediate supplies, proximity to final markets, and a host of other attributes that influence the desirability of an investment location. Furthermore, the various tax and regulatory policies that are relevant to foreign investors may be correlated with non-tax features of economies that independently affect FDI levels. Consequently, it is necessary to interpret evidence of the effect of taxation with considerable caution.

The empirical literature on the effect of taxes on FDI considers almost exclusively U.S. data, either the distribution of U.S. direct investment abroad, or the FDI patterns of foreigners who

\footnotetext{
${ }^{6}$ See Hines $(1997,1999)$ for further elaboration and critical analysis of many of the studies surveyed in this section. ${ }^{7}$ FDI consists of changes in the ownership claims of controlling foreign investors. For example, an American parent firm that establishes a wholly-owned foreign affiliate with $\$ 100$ million of equity and $\$ 50$ million of loans from the parent company thereby creates $\$ 150$ million of FDI. In order for foreign investment to count as FDI, the American investor must own at least 10 percent of the foreign affiliate. FDI is the sum of parent fund transfers and American owners' shares of their foreign affiliates' reinvested earnings, minus any repatriations to American owners. Prior to 1974, the United States reported FDI only for investments in which American owners held at least 25 percent ownership shares. Reported FDI typically represents book values.
} 
invest in the United States. ${ }^{8}$ The simple explanation for this focus is not only that the United States is the world's largest economy, but also that the United States collects and distributes much more, and higher-quality, data on FDI activities than does any other country.

The available evidence of the effect of taxation on FDI comes in two forms. The first is time-series estimation of the responsiveness of FDI to annual variation in after-tax rates of return. Implicit in this estimation is a q-style investment model in which contemporaneous average aftertax rates of return serve as proxies for returns to marginal FDI. Studies of this type consistently report a positive correlation between levels of FDI and after-tax rates of return at industry and country levels. ${ }^{9}$ The implied elasticity of FDI with respect to after-tax returns is generally close to unity, which translates into a tax elasticity of investment of roughly -0.6. The estimated elasticity is similar whether the investment in question is American direct investment abroad or FDI by foreigners in the United States.

The primary limitation of aggregate time-series studies is that they are identified by yearly variation in taxes or profitability that may be correlated with important omitted variables. As a result, it becomes very difficult to distinguish the effects of taxation from the effects of other variables that are correlated with tax rates.

Two of the time-series studies exploit cross-sectional differences that offer the potential for greater explanatory power. Slemrod (1990) distinguishes FDI in the United States by the tax regime in the country of origin, comparing the behavior of investors from with tax systems similar to that used by the United States to the behavior of investors whose home countries exempt foreign profits from taxation. He finds no clear empirical pattern indicating that investors from countries that exempt U.S. profits from home-country taxation are more sensitive to U.S. tax changes than are investors from countries granting foreign tax credits. Swenson (1994) reports that industries in which the (U.S.) after-tax cost of capital rose the most after passage of the U.S. Tax Reform Act of 1986 were those in which foreign investors concentrated their FDI in the post-1986 period, which is consistent with the tax incentives of foreign investors from countries granting foreign tax credits.

\footnotetext{
${ }^{8}$ Devereux and Freeman (1995) and Hines (2001) are recent exceptions.

${ }^{9}$ See, for example, Hartman (1984), Boskin and Gale (1987), Newlon (1987), Young (1988), Slemrod (1990), and Swenson (1994).
} 
Other studies of investment location are exclusively cross-sectional in nature, exploiting the very large differences in corporate tax rates around the world to identify the effects of taxes on FDI. Grubert and Mutti (1991) and Hines and Rice (1994) estimate the effect of national tax rates on the cross-sectional distribution of aggregate American-owned property, plant and equipment (PPE) in 1982. Grubert and Mutti analyze the distribution of PPE in manufacturing affiliates in 33 countries, reporting a -0.1 elasticity with respect to local tax rates. That is, controlling for other observable determinants of FDI, ten percent differences in local tax rates are associated with one percent differences in amounts of local PPE ownership in 1982. Hines and Rice consider the distribution of PPE in all affiliates in 73 countries, reporting a much larger -1 elasticity of PPE ownership with respect to tax rates. Altshuler, Grubert and Newlon (2001) compare the tax sensitivity of aggregate PPE ownership in 58 countries in 1984 to that in 1992, reporting estimated tax elasticities that rise (in absolute value) from -1.5 in 1984 to -2.8 in 1992. Hines (2001) compares the distribution of Japanese and American FDI around the world, finding Japanese investment to be concentrated in countries with which Japan has "tax sparing" agreements that reduce home country taxation of foreign income; the estimated FDI impact of "tax sparing" is consistent with the tax elasticity of PPE reported by Hines and Rice. Hines (1996) compares the distributions of FDI within the United States of investors whose home governments grant foreign tax credits for federal and state income taxes with those whose home governments do not tax income earned in the United States. One percent state tax rate differences in 1987 are associated with ten percent differences in amounts of manufacturing PPE owned by investors from countries with differing home-country taxation of foreign-source income, and three percent differences in numbers of affiliates owned, implying a tax elasticity of investment equal to -0.6 .

\subsubsection{International tax avoidance}

One of the important issues in considering the impact of taxation on international investment patterns is the ability of multinational firms to adjust the reported location of their taxable profits. To the extent that FDI can facilitate the advantageous relocation of profits, then

firms will have incentives to tailor their international investment strategies with such relocation in mind. Hence any complete analysis of the impact of taxation on the operations of multinational firms must necessarily consider the ability and evident willingness of multinational firms to undertake activities to avoid international tax obligations. 
The financing of foreign affiliates presents straightforward opportunities for international tax avoidance. If an American parent company finances its investment in a foreign subsidiary with equity funds, then its foreign profits are taxable in the host country and no taxes are owed the U.S. government until the profits are repatriated to the United States. The alternative of financing the foreign subsidiary with debt from the parent company generates interest deductions for the subsidiary that reduce its taxable income, and generates taxable interest receipts for the parent company.

Simple tax considerations therefore often make it attractive to use debt to finance foreign affiliates in high-tax countries and to use equity to finance affiliates in low-tax countries. ${ }^{10}$ The evidence is broadly consistent with these incentives. Hines and Hubbard (1990) find that the average foreign tax rate paid by subsidiaries remitting nonzero interest to their American parent firms in 1984 exceeds the average foreign tax rate paid by subsidiaries with no interest payments, while the reverse pattern holds for dividend payments. Grubert (1998) estimates separate equations for dividend, interest, and royalty payments by 3467 foreign subsidiaries to their parent American companies (and other members of controlled groups) in 1990, finding that high corporate tax rates in countries in which American subsidiaries are located are correlated with higher interest payments and lower dividend payout rates.

Contractual arrangements between related parties located in countries with different tax rates offer numerous possibilities for sophisticated tax avoidance. It is widely suspected that firms adjust transfer prices used in within-firm transactions with the goal of reducing their total tax obligations. Multinational firms typically can benefit by reducing prices charged by affiliates in high-tax countries for items and services provided to affiliates in low-tax countries. OECD governments require firms to use transfer prices that would be paid by unrelated parties, but enforcement is difficult, particularly when pricing issues concern unique items such as patent rights. Given the looseness of the resulting legal restrictions, it is entirely possible for firms to adjust transfer prices in a tax-sensitive fashion without even violating any laws.

The evidence of tax-motivated transfer pricing comes in several forms. Grubert and Mutti (1991) and Hines and Rice (1994) analyze the aggregate reported profitabilities of U.S affiliates in 
different foreign locations in 1982. Grubert and Mutti examine profit/equity and profit/sales ratios of U.S.-owned manufacturing affiliates in 29 countries, while Hines and Rice regress the profitability of all U.S.-owned affiliates in 59 countries against capital and labor inputs and local productivities. Grubert and Mutti report that high taxes reduce the reported after-tax profitability of local operations; Hines and Rice find considerably larger effects (one percent tax rate differences are associated with 2.3 percent differences in before-tax profitability) in their data. While it is possible that high tax rates are correlated with other locational attributes that depress the profitability of foreign investment, competitive conditions typically imply that after-tax rates of return should be equal in the absence of tax-motivated income-shifting. The fact that before-tax profitability is negatively correlated with local tax rates is strongly suggestive of active tax avoidance.

Harris, Morck, Slemrod and Yeung (1993) report that the U.S. tax liabilities of American firms with tax haven affiliates are significantly lower than those of otherwise-similar American firms over the 1984-1988 period, which may be indirect evidence of aggressive transfer-pricing by firms with tax haven affiliates. Collins, Kemsley and Lang (1998) analyze a pooled sample of U.S. multinationals over 1984-1992, finding a similar pattern of greater reported foreign profitability (normalized by foreign sales) among firms facing foreign tax rates below the U.S. rate. And Klassen et al. (1993) find that American multinationals report returns on equity in the United States that rose by 10 percent relative to reported equity returns in their foreign operations following the U.S. tax rate reduction in 1986.

Patterns of reported profitability are consistent with other indicators of aggressive taxavoidance behavior, such as the use of royalties to remit profits from abroad and to generate tax deductions in host countries. Hines (1995) finds that royalty payments from foreign affiliates of American companies in 1989 exhibit a -0.4 elasticity with respect to the tax cost of paying royalties, and Grubert (1998) also reports significant effects of tax rates on royalty payments by American affiliates in 1990. Clausing (2001) finds that reported trade patterns between American parent companies and their foreign affiliates, and those between foreign affiliates located in different countries, are consistent with transfer-pricing incentives. Controlling for various affiliate

\footnotetext{
${ }^{10}$ Hines (1994) identifies exceptions to this rule that stem from the benefits of limiting equity finance in affiliates located in countries with very low tax rates in anticipation of reinvesting all of their after-tax profits over long periods.
} 
characteristics, including their trade balances with unaffiliated foreigners, Clausing finds that ten percent higher local tax rates are associated with 4.4 percent higher parent company trade surpluses with their local affiliates, which is suggestive of pricing practices that move taxable profits out of high-tax jurisdictions. Swenson (2001) finds a similar pattern in the reported prices of goods imported into the United States, in which high unit tariff rates appear to be associated with unusually low prices.

\subsection{The Role of Chains of Ownership in Multinational Investment}

The ability to use of chains of ownership, whereby affiliates are owned indirectly through other affiliates rather than directly by a parent, can make investors from home countries that tax worldwide incomes but grant foreign tax credits considerably more sensitive to foreign tax rate differences than they would be otherwise. Chains of ownership have this effect by reducing the burden of home-country taxes. In doing so, chains of ownership mitigate the feature of foreign tax credit systems that provide investors with limited incentive to avoid foreign taxes as they are entitled to claim credits against home-country taxes. There are two methods of using chains of ownership to avoid home country taxes, both of which expand opportunities for deferral of home-country taxation.

Altshuler and Grubert (2002) outline these two indirect ownership strategies, which are presented in Figure 1. In the first strategy, depicted in the top panel, foreign earnings that would otherwise be repatriated are used to purchase equity in other existing foreign affiliates. This triangular strategy (so called because ownership of the indirectly held affiliate is split between the parent and one of its affiliates, producing a triangular ownership chart) adds to or replaces the original equity from the parent in the indirectly held affiliate with earnings from the operations of another foreign affiliate. As long as affiliates own at least ten percent of the other foreign operations in which they invest (thereby making such investments "active" from the standpoint of the U.S. tax system), they can continue to defer U.S. taxation of their foreign income until the income is ultimately repatriated. Triangular strategies are limited by the size of indirectly owned affiliates, given that directly held affiliates may have more earnings than can be easily shielded by this strategy. 
The second indirect ownership strategy is one in which a multinational firm uses retained earnings from foreign operations to capitalize its initial investments in new foreign affiliates. The parent firm then has no direct ownership stake in the new foreign affiliate, instead owning it indirectly through one or more tiers of other foreign affiliates. This multiple-tiers strategy, depicted in the bottom panel of Figure 1, also provides for the reallocation of earnings that would otherwise face repatriation taxes but, in this case, through the capitalization of new affiliates within a parent system. The function of this strategy is similar to that of the triangular strategy, in that it reduces the cost of repatriation taxes by deferring repatriation. ${ }^{11}$

Since both the triangular strategy and the multiple-tiers strategy of indirect ownership are intended to facilitate deferral of home country taxes, it follows that the types of investments that firms pursue with such strategies are those for which long periods of time are expected to elapse prior to receiving investment returns. While such payoff patterns defer home country taxes on foreign income, which is advantageous under any circumstances, these payoff patterns become particularly valuable when the investment principle, the retained earnings of affiliates in this case, is itself subject to repatriation taxes. Hence firms have incentives to finance their longestduration foreign projects with the retained earnings of foreign affiliates that would be taxable if immediately repatriated to the United States.

Long-duration foreign investment projects benefit sufficiently from deferral that they can effectively eliminate the burden of repatriation taxes, thereby giving firms incentives to invest based on after-tax foreign returns without reference to the tax consequences of repatriation. In order to illustrate this feature, consider a $\$ 1$ investment by a foreign affiliate whose income is taxed by the foreign country at rate $\bar{\tau}^{*}$. If immediately repatriated, this $\$ 1$ would be subject to a U.S. tax obligation of $\frac{(1-\tau)}{\left(1-\bar{\tau}^{*}\right)}$, net of foreign tax credits, in which $\tau$ is the U.S. corporate tax rate. If instead the $\$ 1$ is invested in a second-tier foreign affiliate that earns an annual pre-tax rate of return of $r^{*}$, and is subject to foreign tax at rate $\tau *$, then after $n$ years the second-tier

\footnotetext{
${ }^{11}$ The triangular and multiple-tiers strategies are versions of the process analyzed by Newlon (1987), Sinn (1993) and Hines (1994), in which parent firms respond to anticipated future repatriation costs by underinvesting initially in foreign affiliates.
} 
foreign affiliate would have net worth of $\left[1+r^{*}\left(1-\tau^{*}\right)\right]^{n}$, which upon repatriation generates an after-tax value $(V)$ of:

$$
V=\frac{(1-\tau)}{\left(1-\tau^{*}\right)}\left[1+r^{*}\left(1-\tau^{*}\right)\right]^{n}-\left[\frac{(1-\tau)}{\left(1-\tau^{*}\right)}-\frac{(1-\tau)}{\left(1-\bar{\tau}^{*}\right)}\right]
$$

The first term on the right side of (1) is the value of the investment in the second-tier foreign affiliate, net of U.S. repatriation taxes (and assuming that the home country of the first-tier foreign affiliate does not tax foreign income). The second term on the right side of (1) corrects the first term for the fact that the $\$ 1$ initial investment generates a foreign tax credit based on a foreign tax rate of $\bar{\tau}^{*}$ rather than $\tau^{*}$.

It is useful to differentiate $V$ separately with respect to $r^{*}$ and $\tau^{*}$ in order to identify the incentives created by deferral and to isolate how the use of chains of ownership approximates the absence of home-country taxation. In the absence of home-country taxation, the value of investment in the foreign affiliate would be determined solely by the after-tax rate of return in the host country, $r *\left(1-\tau^{*}\right)$. Hence the derivative of the value of the investment with respect to $\tau^{*}$ would equal $-r^{*}$, and the derivative of the value of the investment with respect to $r^{*}$ would equal $\left(1-\tau^{*}\right)$, so the ratio of these two derivatives equals $-\frac{r^{*}}{\left(1-\tau^{*}\right)}$. In the case of an investment that employs indirect ownership as described by (1), the ratio of these derivatives is given by:

$$
\frac{\frac{\partial V}{\partial \tau^{*}}}{\frac{\partial V}{\partial r^{*}}}=-\frac{r^{*}}{\left(1-\tau^{*}\right)}+\frac{\left[1+r^{*}\left(1-\tau^{*}\right)\right]}{n\left(1-\tau^{*}\right)^{2}}\left\{1-\left[1+r^{*}\left(1-\tau^{*}\right)\right]^{-n}\right\} .
$$

For long-lasting investments with large $n$, the second term on the right side of (2) becomes insignificant, so the ratio of the two derivatives equals $-\frac{r^{*}}{\left(1-\tau^{*}\right)}$, just as in the absence of home-country taxation. Hence lengthy deferral, in combination with the capitalization of affiliates with earnings that would otherwise bear repatriation taxes, creates incentives that are approximately identical to those facing firms from countries that exempt foreign income from 
taxation. Since indirect ownership strategies are targeted at investments that permit deferral of home country taxes, investment behavior using these strategies should resemble that of investors from exemption countries.

The use of chains of ownership to mitigate the costs of repatriation taxes carries implications for the nature of international tax competition. The equilibrium of competitive tax setting in a Nash framework is that source-based capital tax rates will be driven to zero. ${ }^{12}$ Gordon (1992) demonstrates that the presence of a large capital exporter that taxes foreign income while granting foreign tax credits can produce a Stackelberg equilibrium that preserves capital taxation. In short, the large country serves as a Stackelberg leader whose statutory tax rate provides a floor on the tax competitive behavior of countries seeking to attract capital. Competing capitalimporting countries need not cut tax rates below the statutory rate of the capital exporting country, as investors from the capital exporting country pay repatriation taxes that neutralize any incentives from lower tax rates in the host country. Since firms from countries that tax worldwide incomes while granting foreign tax credits are desensitized to tax rate differences due to the interactions of repatriation taxes and host country taxes, tax competition between potential host countries is consequently reduced.

The ability to structure worldwide operations with chains of ownership effectively neutralizes the burden of repatriation taxes, thereby undoing its induced limitation on tax competition. As investors from foreign tax credit countries are able to mitigate or avoid repatriation taxes, the floor on tax competition is lowered or removed. The use of chains of ownership together with countries that exempt foreign income from taxation consequently creates a competitive dynamic between tax systems that is not based on rates. In a federation or world without exemption countries, chains of ownership are of limited help in allowing firms to avoid repatriation taxes. The presence of exemption countries provides a mechanism to accelerate tax competition between countries seeking to attract flows from foreign tax credit countries given the opportunities afforded by chains of ownership. This externality provided by exemption systems is distinct from rate-cutting behavior more generally. As such, chains of ownership employed by

\footnotetext{
${ }^{12}$ This outcome is an application of productive efficiency as analyzed by Diamond and Mirrlees (1971). See Gordon and Hines (2002) for an interpretive review of this literature and subsequent developments.
} 
multinationals from foreign tax credit countries can increase sensitivity to local tax rates, and exemption countries that facilitate their usage therefore accelerate tax competition.

Indirect ownership of foreign affiliates also carries implications for related empirical studies of foreign direct investment. Borga and Mataloni (2001) highlight the problematic measurement issues related to the rising use of holding companies. In particular, they suggest that assets associated with chains of ownership may be double-counted in worldwide assessments of the activities of U.S. multinationals. Altshuler and Grubert (2002) document the use of passive assets and indirect ownership as means to avoid repatriation taxes in a cross-section of U.S. multinationals in 1996. Desai, Foley and Hines $(2001,2002)$ compare the behavior of directly and indirectly owned subsidiary and branch affiliates to identify the importance of tax and non-tax factors in the dividend policies of a panel of multinational firms between 1982 and 1997.

\section{3. $\quad$ Framework and Data}

This section presents a model of multinational investment in which firms are able to adjust reported profitability in response to tax rate differences. This framework is useful in establishing and interpreting the behavior of American multinational companies, as analyzed in section 4. This section also describes the data used in the empirical analysis, and considers some of their features.

\subsection{Framework $^{13}$}

Consider the case in which a firm earns pretax profits of $\rho_{i}$ in country $i$, but has the option of adjusting its reported profitability through the use of creative financing, transfer price adjustment, and other methods. Suppose that the firm amends its financing and transfer prices to allocate an additional $\psi_{i}$ in profits to location $i$. This process is likely to be costly, for reasons that are familiar: the firm may need to establish additional facilities in order to make transfer prices seem plausible, legal costs may be incurred, and (inefficient) intrafirm trades may take place to facilitate profit reallocation. It is plausible to hypothesize that that the marginal cost of shifting

profits into a location is small at first, but rises in proportion to the $\frac{\psi_{i}}{\rho_{i}}$ ratio. Letting $\alpha$ denote this

\footnotetext{
${ }^{13}$ This section draws on Hines and Rice (1994).
} 
factor of proportionality, the total cost of adjusting local reported profits equals $\frac{\alpha \psi_{i}^{2}}{2 \rho_{i}}$. Hence the reported profitability of affiliate $i, \pi_{i}$, is:

$$
\pi_{i}=\rho_{i}+\psi_{i}-\frac{\alpha \psi_{i}^{2}}{2 \rho_{i}}
$$

Note that $\psi_{i}<0$ for an affiliate that transfers some of its profits out to other locations. Firms are assumed to incur costs for shifting profits in any direction between locations, including overreporting profits in some locations, since doing so typically entails undertaking costly actions. The firm is constrained to have the sum of $\psi_{i}$ nonpositive, since transfers do not create additional profits.

Consider the behavior of a multinational firm that chooses its profit transfers $\left(\psi_{i}\right)$ to maximize after-foreign-tax returns $(R)$, taking as fixed the profits earned by its factors $\left(\rho_{i}\right)$ :

$$
R \equiv \sum_{i=1}^{n}\left(1-\tau_{i}\right) \pi_{i}=\sum_{i=1}^{n}\left(1-\tau_{i}\right)\left[\rho_{i}+\psi_{i}-\frac{\alpha \psi_{i}^{2}}{2 \rho_{i}}\right],
$$

subject to:

$$
\sum_{i=1}^{n} \psi_{i}=0
$$

This maximization problem yields the first-order condition:

$$
\left(1-\tau_{i}\right)\left[1-\alpha\left(\frac{\psi_{i}}{\rho_{i}}\right)\right]=\lambda
$$

in which $\lambda$ is the Lagrange multiplier corresponding to the constraint in (5). Then (6) implies that

$$
\psi_{i}=\rho_{i}\left[\frac{1-\tau_{i}-\lambda}{\alpha\left(1-\tau_{i}\right)}\right]
$$


Combining (7) and (4),

$$
\pi_{i}=\rho_{i}\left[1+\frac{1}{2 \alpha}-\frac{\lambda^{2}}{2 \alpha\left(1-\tau_{i}\right)^{2}}\right]
$$

Equation (8) indicates that reported profitability $\left(\pi_{i}\right)$ is a function of pretax profits $\left(\rho_{i}\right)$ and local tax rates. In order to estimate (8), it is useful to transform the term on the right side into a linear function of tax rates. Note that if $\tau_{i}=(1-\lambda)$, then $\pi_{i}=\rho_{i}$. Taking a first-order Taylor expansion of (8) in $\tau_{i}$, around the point at which $\tau_{i}=(1-\lambda)$, yields:

$$
\pi_{i}=\rho_{i}-\rho_{i}\left[\frac{\tau_{i}-(1-\lambda)}{\alpha \lambda}\right]
$$

It follows, therefore, that reported profitability exceeds earned profits in low tax countries, and is less than earned profits in high tax countries. One can interpret the Lagrange multiplier $\lambda$ either as a parameter that captures the marginal cost of transferring profits between locations, or as the tax rate of the marginal country neither into which, nor out of which, firms transfer profits.

The envelope theorem implies that the value of earning an additional dollar of pre-tax profits $\left(\rho_{i}\right)$ in location $i$ can be evaluated assuming that $\psi_{i}$ does not adjust in response. Hence the value of additional profitability is indicated by equation (4). Firms allocate any given stock of capital $(\bar{K})$ to maximize (4) subject to the constraint:

$$
\sum_{i=1}^{n} K_{i} \leq \bar{K}
$$

The first-order condition for this maximization problem is:

$$
\frac{d \rho_{i}}{d K_{i}}\left(1-\tau_{i}\right)\left[1+\frac{\alpha \psi_{i}^{2}}{2 \rho_{i}^{2}}\right]=\mu,
$$

in which $\mu$ is a constant for all locations, and reflects the value of relaxing the resource constraint (10) by one unit. Imposing (7) then produces: 


$$
\frac{d \rho_{i}}{d K_{i}}\left(1-\tau_{i}\right)\left[1+\frac{\left(1-\tau_{i}-\lambda\right)^{2}}{2 \alpha\left(1-\tau_{i}\right)^{2}}\right]=\mu
$$

If equation (12) took the form that $\frac{d \rho_{i}}{d K_{i}}\left(1-\tau_{i}\right)$ were the same in all locations, then it would have the familiar feel of investment equations in which after-tax marginal returns were equalized everywhere. Instead, (12) is slightly different, since it incorporates the ability of multinational firms to transfer profits between jurisdictions; this subtle change reflects the added value of earning profits in low-tax locations when doing so facilitates profitable reporting of taxable income. For values of $\tau_{i}$ in the neighborhood of $(1-\lambda)$ this consideration is unimportant, since firms do not reallocate their taxable incomes even though they have the option of doing so. A first-order Taylor expansion of (12) in $\tau_{i}$, around the point at which $\tau_{i}=(1-\lambda)$, yields:

$$
\frac{d \rho_{i}}{d K_{i}}\left(1-\tau_{i}\right)=\mu
$$

In order to estimate the investment behavior implied by (13) it is useful to consider the simple production function specification:

$$
\rho_{i}=\theta_{i} K_{i}^{\gamma}
$$

in which $\theta_{i}$ is a country-specific vector of observable attributes such as powers of GNP, and $\gamma$ is a parameter that reflects the curvature of the production function. Differentiating both sides of (14) with respect to $K_{i}$, imposing (13), and rearranging terms, yields:

$$
K_{i}^{1-\gamma}=\frac{\left(1-\tau_{i}\right) \theta_{i} \gamma}{\mu} .
$$

Taking natural logs of both sides of (15), and using the Taylor approximation that $\ln \left(1-\tau_{i}\right) \approx-\frac{\tau_{i}}{\lambda}$ yields:

$$
\ln \left(K_{i}\right) \approx \beta_{0}-\beta_{1} \tau_{i}
$$




$$
\begin{aligned}
& \beta_{0}=\frac{\left[\ln \left(\theta_{i} \gamma\right)-\ln (\mu)\right]}{(1-\gamma)} \\
& \beta_{1}=\frac{1}{\lambda(1-\gamma)} .
\end{aligned}
$$

The empirical work that follows estimates variants of the profit allocation equation (9) and the investment equation (16) with particular emphasis on the distinctive incentives created by chains of ownership.

\subsection{Data}

The Bureau of Economic Analysis (BEA) annual survey of U.S. Direct Investment Abroad from provides data on the financial and operating characteristics of U.S. firms operating abroad, and this study uses data covering the years 1982 through 1997. These surveys require respondents to file detailed financial and operating items for each foreign affiliate and provide information on the value of transactions between U.S. parents and their foreign affiliates. The International Investment and Trade in Services Survey Act governs the collection of the data and the Act ensures that "use of an individual company's data for tax, investigative, or regulatory purposes is prohibited." Willful noncompliance with the Act can result in penalties of up to $\$ 10,000$ or a prison term of one year. As a result of these assurances and penalties, BEA believes that coverage is close to complete and levels of accuracy are high. ${ }^{14}$

U.S. direct investment abroad is defined as the direct or indirect ownership or control by a single U.S. legal entity of at least ten percent of the voting securities of an incorporated foreign business enterprise or the equivalent interest in an unincorporated foreign business enterprise. A U.S. multinational entity (MNE) is the combination of a single U.S. legal entity that has made the direct investment, called the U.S. parent, and at least one foreign business enterprise, called the foreign affiliate. In order to be considered as a legitimate foreign affiliate, the foreign business enterprise should be paying foreign income taxes, have a substantial physical presence abroad, have separate financial records, and should take title to the goods it sells and receive revenue from sales. In order to determine ownership stakes in the presence of indirect ownership, BEA 
determines the percentage of parent ownership at each link in the ownership chain and then multiplies these percentages to compute the parent's total effective ownership.

BEA collects sufficient information to link affiliate level data through time to create a panel. By checking the status of all affiliates that filed forms in the previous year and are expected to fall within reporting requirements, BEA identifies which enterprises leave the sample. By monitoring news services for information on mergers, acquisitions, and other activities of U.S. companies, BEA identifies which new enterprises should be included in the sample. To check the integrity of reported data, BEA accountants confirm that information satisfies certain integrity checks.

The foreign affiliate survey forms that US MNEs are required to complete vary depending on the year, the size of the affiliate, and the U.S. parent's percentage of ownership of the affiliate. For the sample covered in this study, the most extensive data are available for 1982, 1989, and 1994, when BEA conducted Benchmark Surveys. In these years, all affiliates with sales, assets, or net income in excess of $\$ 3$ million in absolute value, and their parents, were required to file reports. In non-benchmark years between 1982 and 1997, exemption levels were higher. From 1983-1988, all affiliates with an absolute value of sales, assets, or net income less than \$10 million were exempt, and this cutoff increased to \$15 million from 1990-1993 and \$20 million from 19951997. While the BEA does estimate data in order to arrive at universe totals, the following analysis excludes estimated data. ${ }^{15}$

To classify the industrial activities of parents and affiliates, BEA assigns each domestic and foreign entity to an international surveys industry (ISI) classification code that is based on the Standard Industrial Classification (SIC) scheme. A typical ISI code roughly covers the same scope of activities as a three-digit SIC code. The classification of foreign affiliate data tends to be precise because parents can consolidate foreign affiliate operations for BEA reporting only if they are in the same country and the same three-digit ISI industry or if they are integral parts of the same

\footnotetext{
${ }^{14}$ Mataloni (1995) provides a detailed description of the BEA data. The BEA data covers the mulinational operations of firms owned by a U.S. person.

${ }^{15}$ BEA uses reported data to estimate universe totals when surveys cover only larger affiliates or when only certain affiliates provide information on particular survey forms. Estimated data is unlikely to have a significant impact on the BEA's published data at the industry or country level as data based on actual reports exceed 90 percent of the estimated totals of assets and sales in each of the years between 1982 and 1997. To avoid working with estimated data, only affiliates required to provide all the information associated with a particular analysis are considered.
} 
business operation. One of the implications of this exclusion is that the results presented below do not reflect patterns in the data driven by holding companies since these firms are classified as financial firms.

Figure 2 illustrates the role of indirect ownership in U.S. foreign direct investment abroad over the 1982-1997 sample period. The three lines on the figure refer to the share of number of affiliates, sales of affiliates, and assets of affiliates accounted for by affiliates with some indirect ownership. As the figure indicates, there has been a dramatic rise in the use of indirect ownership. The coverage of indirect ownership seems to be more complete in benchmark years, yielding spikes in the three lines in 1982, 1989, 1994. Therefore, if a comparison is made between 1983, the first non-benchmark year, and 1997, the last non-benchmark year, the figure indicates that the share of affiliates that were completely indirectly owned increases from 21 percent to 27 percent. This increase appears larger when measured in terms of the shares of sales and assets, implying that indirectly owned affiliates also grow more rapidly in size than directly owned affiliates during this period. The share of sales accounted for by indirectly owned affiliates increased from 18 percent to 32 percent, and the share of assets increased from 14 percent to 38 percent.

Table 1 displays descriptive statistics for affiliates that are entirely directly owned and affiliates with some indirect ownership in the last three benchmark years, 1982, 1989, and 1994; and the last year in the sample, 1997. In 1997, those affiliates that were completely directly owned had mean sales of $\$ 153$ million, mean assets of \$205 million, and mean employment of 541 . Median measures of these three items are significantly smaller, indicating the presence of some very large affiliates. Although affiliates with some indirect ownership and affiliates with no indirect ownership were of a similar or smaller size in terms of sales and assets in the early part of the sample, they were substantially larger than completely owned affiliates by the end of the sample, as implied by Figure 2. In 1997, those affiliates with some indirect ownership reported mean sales of \$200 million, and mean assets of \$205 million; these figures are more than 20 percent larger than the figures reported by affiliates that are directly owned. However, both types of affiliates are of similar size when measured by employment.

Table 2 presents data for 1982, 1989, 1994 and 1997 on the use of indirect ownership for the twenty countries containing the largest number of affiliates in 1997. For each country in each 
year, the first column of data provides a count of the number of reporting affiliates and the second column indicates the share of those affiliates that had at least some indirect ownership. This table illustrates that indirect ownership is particularly prevalent and increasing in Europe. In 1997, the share of reporting affiliates with indirect ownership was 17.0 percent in the Americas, 24.1 percent in Asia and Australia and 33.0 percent in Europe. Considering the evidence across benchmark years (to facilitate comparability) also suggests that Europe is characterized by an increasing prevalence of indirect ownership, with most of its growth appearing after 1989, while affiliates in the Americas actually exhibit declining use of indirect ownership. Despite these striking regional differences, there exists considerable heterogeneity among countries, with some Asian countries, such as China, featuring high levels of indirect ownership while some European countries, such as Switzerland, feature more modest levels of indirect ownership. Table 3 provides the country tax rates, as constructed and employed in the regression analysis presented below, for these same major countries and specific years. ${ }^{16}$

Table 4 presents information on the location of the intermediate owners of indirectly owned affiliates in 1997. The left panel of Table 4 indicates that U.S. owned affiliates in the Netherlands own 652 other affiliates, representing 21.4 percent of the total stock of indirectly owned American affiliates. Intermediate owners are heavily concentrated in Western Europe and Canada, and with the exception with those affiliates located in the United Kingdom, are concentrated among countries that exempt foreign profits from taxation. Countries in which U.S. owned firms employ the most labor and capital tend to be homes to the greatest volumes of indirect ownership, suggesting that indirect ownership is commonly associated with active multinational operations.

The right panel of Table 4 describes the geographic distribution of intermediate owners of European affiliates. U.S. owned affiliates located in the Netherlands again top the list, owning 532 European affiliates, or 26.2 percent of all indirectly held European affiliates. The seven leading homes for intermediate owners of European affiliates are all European countries, together hosting the ownership of more than 85 percent of indirectly held European affiliates. The absence of withholding taxes on inter-company dividend flows within Europe makes European affiliates

\footnotetext{
${ }^{16}$ Effective income tax rates are calculated by taking the ratio of the sum of foreign income taxes to the sum of net income and foreign income taxes in each country and year. Affiliate observations in which the affiliate reports
} 
natural owners of indirectly held European operations, and there may also be informational and regulatory advantages to cross-ownership within Europe.

\section{Results}

Data on the activities of U.S. owned firms between 1982 and 1997 are used to estimate the extent to which host country taxation affects both the volume of investment and the location of taxable profits. The focus of the estimation is to identify features, such as indirect ownership of affiliates, or the European location of affiliates, that contribute to their tax sensitivity.

\subsection{Foreign Direct Investment}

Table 5 presents the results of estimating equation (16) on the sample described in section 3. The dependent variable is these regressions is the natural log of an affiliate's total assets; the independent variables in all the regressions include country tax rates ${ }^{17}$ as well as $\ln (G N P)$, $[\ln (G N P)]^{2}$, and $[\ln (G N P)]^{3}$. Estimated coefficients on $\ln (G N P),[\ln (G N P)]^{2}$, and $[\ln (G N P)]^{3}$ are not reported, for the reasons that they are more or less intuitive (larger economies receive greater volumes of foreign direct investment, though this relationship is generally nonlinear) and not the focus of the study. In the regression reported in column 1 of Table 5 , the -0.7409 coefficient on the country tax rate implies that ten percent lower tax rates are associated with 7.4 percent greater affiliate assets, controlling for three powers of host country GNP. This coefficient carries the same sign as those in the literature, though the estimated effect is of somewhat greater magnitude than that reported by most other studies that use different data and estimating methods. ${ }^{18}$

One difficulty with interpreting the tax rate coefficient reported in column 1 is that the equation specification does not control for non-GDP determinants of investment, particularly those that vary between companies and over time. Column 2 of Table 5 reports estimated coefficients from a regression that includes a full set of year dummy variables and parent company dummy

negative net income are excluded from this calculation. Tax rates are constructed in this way in order to capture the effects of differences in tax base definitions, special incentives for foreign direct investment, and other important aspects of tax systems that are not reflected in statutory tax rate differences.

${ }^{17}$ Measured tax rates reflect features of investment activity that differ between countries, though they are unaffected by the volume of investment of individual affiliates, and are therefore appropriate as independent variables in the investment and income allocation equations. Further, measured tax rates closely track statutory tax rates. See Desai, Foley and Hines (2001) for further discussion of tax rate calculations.

${ }^{18}$ The standard errors presented in Tables 5-8 are clustered at the country/year level. 
variables. As a result, firm-specific considerations such as a company's primary industry implicitly do not affect the estimates reported in column 2. The estimated tax rate effect declines to -0.4956 , implying that 10 percent lower tax rates are associated with 5.0 percent greater assets. This estimated tax effect is quite close to those obtained in FDI studies using different data and methods. In particular, previous estimates of tax effects come from regressions that do not control for identities of parent companies in estimating the effects of tax rate difference on the location of investment by affiliates.

The regressions reported in columns 3 and 4 of Table 5 add Europe-specific variables in order to distinguish European tax effects from those in other parts of the world. Estimated coefficients on the Europe dummy variable (that takes the value one if a host country is European, and is zero otherwise), and the interaction of this dummy variable with host country tax rates, are insignificant in the regression reported in column 3. Adding year and parent company fixed effects, as in the regression reported in column 4, yields a positive coefficient on the Europe dummy variable and a negative coefficient on the interaction of the Europe dummy variable and the host country tax rate. These results reflect first that American firms invest greater resources in European countries than they would in other countries with similar GNPs, which is unsurprising. The more notable feature of the results is that investments within Europe exhibit considerably greater tax sensitivity than do investments generally. The results reported in column 4 imply that, for countries outside of Europe, 10 percent higher tax rates are associated with 2.3 percent reduced investment, while for European countries, 10 percent higher tax rates are associated with 7.7 percent reduced investment. One interpretation of this pattern is that the similarity of European economies and the effects of integration brought about by the European Union have intensified competitive pressures within Europe.

It is possible to interact European tax effects with a time trend in order to test whether tax competition appears to have intensified over time. Columns 5 and 6 of Table 5 report the results of regressions that include such time interactions; they do not offer support to the notion that competitive pressures within Europe have intensified over the sample period (1983-1997). The estimated coefficient on the interaction of the European dummy variable, the time trend, and the host country tax rate is positive and insignificant in the regression reported in column 6; increasing competition would imply that this coefficient is negative. 
Columns 7 and 8 of Table 5 report estimated coefficients from regressions that add a dummy variable for Asian affiliates and an interaction between this dummy variable and the local tax rate. These specifications retain the European dummy variable and European tax interaction. The estimated coefficients on the Asia-specific variables are small in magnitude and statistically insignificant, suggesting that American investment in Asian countries exhibits the same tax sensitivity as that of American investment in the rest of the non-European world.

Columns 9 and 10 of Table 5 report estimated coefficients from regressions that add dummy variables and tax interactions for American investment in Latin American countries (that include all Western Hemisphere investment other than Canada). The regression results imply a considerable tax sensitivity of American investment within Latin America. The -1.0118 coefficient on the interaction of the Latin America dummy variable and the tax rate, reported in column 10, implies that 10 percent lower tax rates in Latin America are associated with 10 percent greater investment. The estimated coefficient on the European tax interaction in the same regression is -0.74 , which, while of somewhat smaller magnitude, is statistically indistinguishable from the Latin America tax effect. Hence it appears that the location of American investment in both Europe and Latin America is strongly affected by local tax rates.

The results reported in Table 5 indicate that American multinational firms locate assets on the basis of firm and country characteristics that, importantly, include local tax rates. These effects appear in regressions that include fixed effects for parent companies, which thereby are identified only on the basis of within-firm distributions of foreign assets. The effects are most pronounced for affiliates located in Europe and Latin America, which is consistent with the availability of nearby substitute locations for investment.

\subsection{Income Location}

Foreign investors locate assets in patterns that are consistent with considerable sensitivity to local tax rates. Tax avoidance of this kind may reflect several alternative aspects of behavior, including the ability to relocate taxable income between jurisdictions. In order to verify that it is reasonable for firms to anticipate subsequently relocating income when making their investment decisions, it is informative to measure the extent to which reported income is sensitive to local tax rates. 
Table 6 presents the results of estimating the determinants of reported income, as captured in equation (9). Column 1 of Table 6 reports coefficients from a very simple regression in which the dependent variable is affiliate after-tax income, and the independent variables are gross assets and the interaction of gross assets and the host country tax rate. The 0.0702 coefficient on gross assets implies that, roughly on average in zero tax rate countries, affiliates earn after-tax returns of 7.02 percent on assets. The -0.0680 estimated coefficient on the interaction of assets and host country tax rate implies that returns fall at higher tax rates; 10 percent higher tax rates are associated with 0.68 percent lower after-tax returns. ${ }^{19}$ Asset market equilibrium with identical investors and free entry normally implies the equality of after-tax returns in different locations, so the observed negative correlation between tax rates and after-tax income is suggestive of active management of reported incomes. Another interpretation is that pretax income location is insensitive to taxes, with after-tax returns then negatively correlated with local tax rates simply by reducing after-tax incomes. In order to distinguish these interpretations, and identify differences between their implications, it is useful to compare the income-location behavior of affiliates in different parts of the world and with different ownership structures.

The regression reported in column 2 of Table 6 adds year and parent fixed effects to the specification of the equation reported in column 1. The results are similar to those appearing in column 1, though the estimated effects are somewhat larger: 10 percent tax rate differences are now associated with 0.90 percent differences in reported returns on assets. Columns 3 and 4 introduce a European dummy variable and its interaction with host country tax rates. In the specification reported in column 4, the profit rates of European affiliates appear to be three times as tax sensitive as those located outside of Europe, after controlling for year and parent effects. Ten percent higher tax rates reduce after-tax European profit rates by 1.7 percent (the sum of 0.55 and 1.15 percents), while they reduce profit rates outside of Europe by 0.55 percent. The insignificant estimated coefficients on interactions of the Europe dummy variable, host country tax rates, and a time trend, reported in columns 5 and 6, imply that there is no obvious trend in the European effect on profitability.

A heightened sensitivity of profits to taxes is not present in Asia or Latin America. The regressions reported in columns 7 and 8 add dummy variables for Asian affiliates, and interactions

\footnotetext{
${ }^{19}$ Across all years and affiliates, the median after-tax return on assets is 5.02 percent.
} 
between these dummy variables and local tax rates. Estimated tax effects are small in magnitude and statistically insignificant in both specifications. The regressions reported in columns 9 and 10 add dummy variables for Latin American affiliates and their interaction with local tax rates. Estimated effects of Latin American tax rates on after-tax profitability are statistically indistinguishable from zero and considerably smaller than estimated European tax effects and tax effects in the rest of the world.

\subsection{Indirect Ownership}

Sections 2 and 3 review the incentives facing U.S. owned multinational firms, noting that indirectly owned affiliates are likely to be more tax sensitive than those that are directly owned, since the profits of indirectly owned affiliates are generally subject to lower effective repatriation taxes by the United States. This section examines the behavior of U.S. owned firms, which is strongly consistent with predicted tax effects.

Table 7 presents estimated coefficients from regressions that distinguish the investment behavior of foreign affiliates that are indirectly owned by U.S. parent firms from those that are directly owned. The estimated coefficients reported in column 1 imply that 10 percent higher tax rates are associated with 4.9 percent fewer assets held by directly owned affiliates, and 15.3 percent (the sum of 4.9 percent and 10.4 percent) fewer assets held by indirectly owned affiliates. This is a very strong effect of taxation on assets owned by indirectly held affiliates. Controlling for year and parent effects, as in the regression reported in column two, produces similar results: 10 percent higher tax rates are associated with 2.6 fewer assets held by directly owned affiliates, and 12.0 percent fewer assets held by indirectly owned affiliates.

European affiliates are more likely than others to be indirectly held, so one possible interpretation of the indirect ownership results is that they largely reflect the tax sensitivity of European investment. Columns 3 and 4 of Table 7 report estimated coefficients from regressions that add interactions with dummy variables for European locations. The estimated tax sensitivity of indirectly owned affiliates changes little when European dummy variables are included in the regressions. In the specification that controls for year and parent effects, reported in column 4, 10 percent higher tax rates are associated with 9.6 percent fewer assets held by indirectly owned affiliates outside Europe, and 13.8 percent fewer assets held by indirectly owned European 
affiliates. The effect of higher tax rates on investment by indirectly owned European affiliates is not statistically different from the effect of higher tax rates on other indirectly owned affiliates, but both differ significantly from the estimated behavior of directly owned affiliates. Hence it appears that, while the investment location of indirectly owned European affiliates may be somewhat more responsive to tax rate differences than is the investment location of other affiliates, European effects do not solely account for the estimated tax-sensitivity of investment by indirectly owned affiliates.

Table 8 presents the results of regressions in which the dependent variable is net after-tax affiliate income, and the independent variables distinguish the effects of tax rates on directly and indirectly owned affiliates. The regression reported in column 2, that includes controls for year and industry effects, indicates that 10 percent higher tax rates reduce the reported profitability of indirectly owned affiliates by 1.4 percent of assets, while reducing the reported profitability of directly owned affiliates by only 0.7 percent of assets. European affiliates continue to exhibit unusual sensitivity of profitability to local tax rates in the regressions, reported in columns 3 and 4 , that include separate tax interactions for European and indirectly owned affiliates. The regression reported in column 4 implies that ten percent higher tax rates reduce the profitability of indirectly held European affiliates by 2.4 percent of assets, while reducing the profitability of other indirectly held affiliates by 0.9 percent of assets, and reducing the profitability of directly held affiliates by 0.4 percent of assets. Tax rate differences have significantly stronger effects on the profitability of indirectly owned affiliates than they do on the profitability of directly owned affiliates in Europe and the rest of the world.

The results presented in Tables 5-8 generally confirm the findings of the literature that high tax rates are associated with reduced investment by multinational firms and with reported profit rates that are lower than industry averages. This tax sensitivity is particularly pronounced among firms that are indirectly owned by their U.S. parent companies, raising the intriguing possibility that multinational firms that are headquartered in countries that exempt foreign income from taxation may exhibit tax avoidance behavior that is stronger than what has previously been documented for American firms. The European affiliates of American companies likewise appear to be unusually sensitive to taxation, which may be a reflection of the close alternatives available within a federation such as Europe. 


\section{Conclusion}

This paper uses affiliate-level data on the behavior of American companies during the 1982-1997 period to investigate the extent to which the location of investment and reported profits is particularly sensitive to tax rate differences when affiliates are located in Europe or are indirectly owned. A growing fraction of American direct investment abroad is conducted by indirectly owned affiliates. Quite apart from intrinsic interest in the effect of indirect ownership given its rising importance, an investigation of the effect of European presence and indirect ownership has the potential to shed light on the behavior of multinational firms in settings in which tax competition is likely to have the greatest sway. The empirical results indicate that asset and income allocation by European and indirectly owned affiliates is indeed unusually sensitive to tax rate differences. (So too, presumably, are other aspects of multinational operations, such as the allocation of employment and production, but the paper does not test these implications.) These findings suggest that previous American evidence on the impact of taxation may, if anything, underestimate the effect of taxation on the behavior of multinational firms around the world.

The ability of multinational firms to use indirect ownership of foreign affiliates to mitigate the incentives created by home country taxation carries important implications for tax competition. If the recent trend of rising indirect ownership continues, then capital-importing countries are likely to feel growing pressure to reduce any source-based taxes they impose on foreign investment. Lower foreign tax rates will in turn encourage American firms to accelerate their use of indirect ownership structures for their foreign investments. The results also raise the possibility that partial European economic integration, without coordination of tax policies, may increase rather than reduce the extent to which tax considerations dictate the allocation of resources within Europe. 


\section{References}

Altshuler R, H Grubert (2002) Repatriation taxes, repatriation strategies and multinational financial policy. Forthcoming in Journal of Public Economics

Altshuler R, H Grubert, TS Newlon (2001) Has US investment abroad become more sensitive to tax rates?. In: JR Hines Jr (ed) International taxation and multinational activity. University of Chicago Press, Chicago, pp 9-32

Borga M, R Mataloni (2001) Direct investment positions for 2000. Survey of Current Business 81(3): 16-29

Boskin M, WG Gale (1987) New results on the effects of tax policy on the international location of investment. In: M Feldstein (ed) The effects of taxation on capital accumulation. University of Chicago Press, Chicago, pp 201-219

Clausing KA (2001) The impact of transfer pricing on intrafirm trade. In: JR Hines Jr (ed) International taxation and multinational activity. University of Chicago Press, Chicago, pp 173194

Collins J, D Kemsley, M Lang (1998) Cross-jurisdictional income shifting and earnings valuation. Journal of Accounting Research 36: 209-229

Desai MA, CF Foley, JR Hines Jr (2001) Repatriation taxes and dividend distortions. National Tax Journal 54(4): 829-851

Desai MA, CF Foley and JR Hines Jr (2002) Dividend policy inside the firm. NBER Working Paper No. 8698

Devereux MP, H Freeman (1995) The impact of tax on foreign direct investment: Empirical evidence and the implications for tax integration schemes. International Tax and Public Finance 2(1): $85-106$

Diamond PA, J Mirrlees (1971) Optimal taxation and public production, I: Production Efficiency (II: Tax Rules). American Economic Review 61:8-27 (261-278)

Gordon RH (1992) Can capital income taxes survive in open economies? Journal of Finance 47: $1159-1180$

Gordon RH, JR Hines Jr (2002) International taxation. Forthcoming in Handbook of Public Economics

Grubert H (1998) Taxes and the division of foreign operating income among royalties, interest, dividends and retained earnings. Journal of Public Economics 68(2): 269-290 
Grubert H, J Mutti (1991) Taxes, tariffs and transfer pricing in multinational corporate decision making. Review of Economics and Statistics 73(2): 285-293

Harris D, R Morck, J Slemrod, B Yeung (1993) Income shifting in US multinational corporations. In: A Giovannini, RG Hubbard, J Slemrod (eds) Studies in international taxation. University of Chicago Press, Chicago, pp 277-302

Hartman DG (1984) Tax policy and foreign direct investment in the United States. National Tax Journal 37(4): 475-487

Hines JR Jr (1991) The flight paths of migratory corporations. Journal of Accounting, Auditing, and Finance 6(4): 447-479

Hines JR Jr (1994) Credit and deferral as international investment incentives. Journal of Public Economics 55(2): 323-347

Hines JR Jr (1995) Taxes, technology transfer, and the R\&D activities of multinational firms. In: M Feldstein, JR Hines Jr, RG Hubbard (eds) The effects of taxation on multinational corporations. University of Chicago Press, Chicago, pp 225-248

Hines JR Jr (1996) Altered states: Taxes and the location of foreign direct investment in America. American Economic Review 86(5): 1076-1094

Hines JR Jr. (1997) Tax policy and the activities of multinational corporations. In: AJ Auerbach (ed) Fiscal policy: Lessons from economic research. MIT Press, Cambridge, pp 401-445

Hines JR Jr (1999) Lessons from behavioral responses to international taxation. National Tax Journal 52(2): 305-322

Hines JR Jr (2001) “Tax sparing” and direct investment in developing countries. In: JR Hines Jr (ed) International taxation and multinational activity. University of Chicago Press, Chicago, pp $39-66$

Hines JR Jr, RG Hubbard (1990) Coming home to America: Dividend repatriations by US multinationals. In: A Razin, J Slemrod (eds) Taxation in the global economy. University of Chicago Press, Chicago, pp 161-200

Hines JR Jr, RG Hubbard (1995) Appendix. In: M Feldstein, JR Hines Jr, RG Hubbard (eds) Taxing multinational corporations. University of Chicago Press, Chicago, pp 103-106

Hines JR Jr, EM Rice (1994) Fiscal paradise: Foreign tax havens and American business. Quarterly Journal of Economics 109(1): 149-182

Mataloni R (1995) A Guide to BEA statistics on US multinational companies. Survey of Current Business 75(3): 38-53 
Newlon TS (1987) Tax policy and the multinational firm's financial policy and investment deicisions. Ph.D. dissertation, Princeton University

Sinn HW (1993) Taxation and the birth of foreign subsidiaries. In: H Herberg, N Van Long (eds) Trade, welfare, and economic policies: Essays in honor of Murray C Kemp. University of Michigan Press, Ann Arbor, pp 325-352

Slemrod J (1990) Tax effects on foreign direct investment in the United States: Evidence from a cross-country comparison. In: A Razin, J Slemrod (eds) Taxation in the global economy. University of Chicago Press, Chicago, pp 79-117

Swenson DL (1994) The impact of US tax reform on foreign direct investment in the United States. Journal of Public Economics 54(2): 243-266

Swenson DL (2001) Tax reforms and evidence of transfer pricing. National Tax Journal 54(1): 725

Young KH (1988) The effects of taxes and rates of return on foreign direct investment in the United States. National Tax Journal 41(1): 109-121 


\section{Figure 1: Use of Chains of Ownership to Mitigate Repatriation Taxes}

\section{Panel A: A Triangular Strategy}

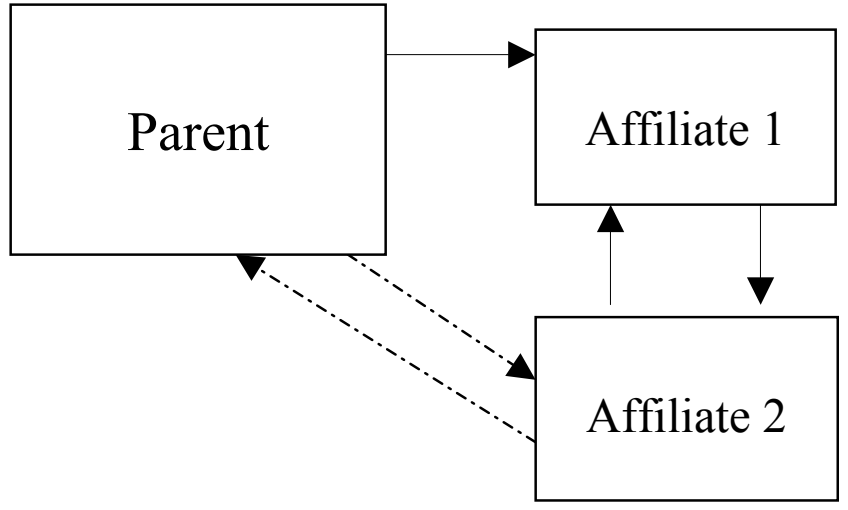

Panel B: A Multiple Tiers Strategy

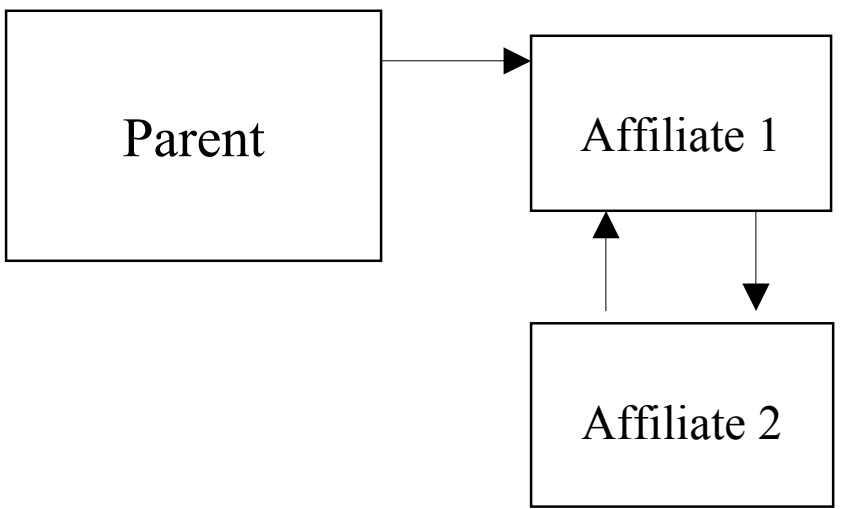

Note: The figure depicts two different indirect ownership strategies designed to defer repatriation of lightly-taxed foreign earnings. In the triangular strategy, the retained earnings of affiliate 1 are invested in the preexisting affiliate 2 , and these earnings replace the parent company's equity capitalization of affiliate 2. In that way, the retained earnings of affiliate 1 are redeployed within the parent system without triggering repatriation taxes. In the multiple tiers strategy, the earnings of affiliate 1 are invested as the equity capitalization of a new affiliate 2 , similarly effecting a redeployment of earnings within the parent system without triggering repatriation taxes. 
Figure 2: The Role of Chains of Ownership in U.S. Direct Investment Abroad, 1982-1997

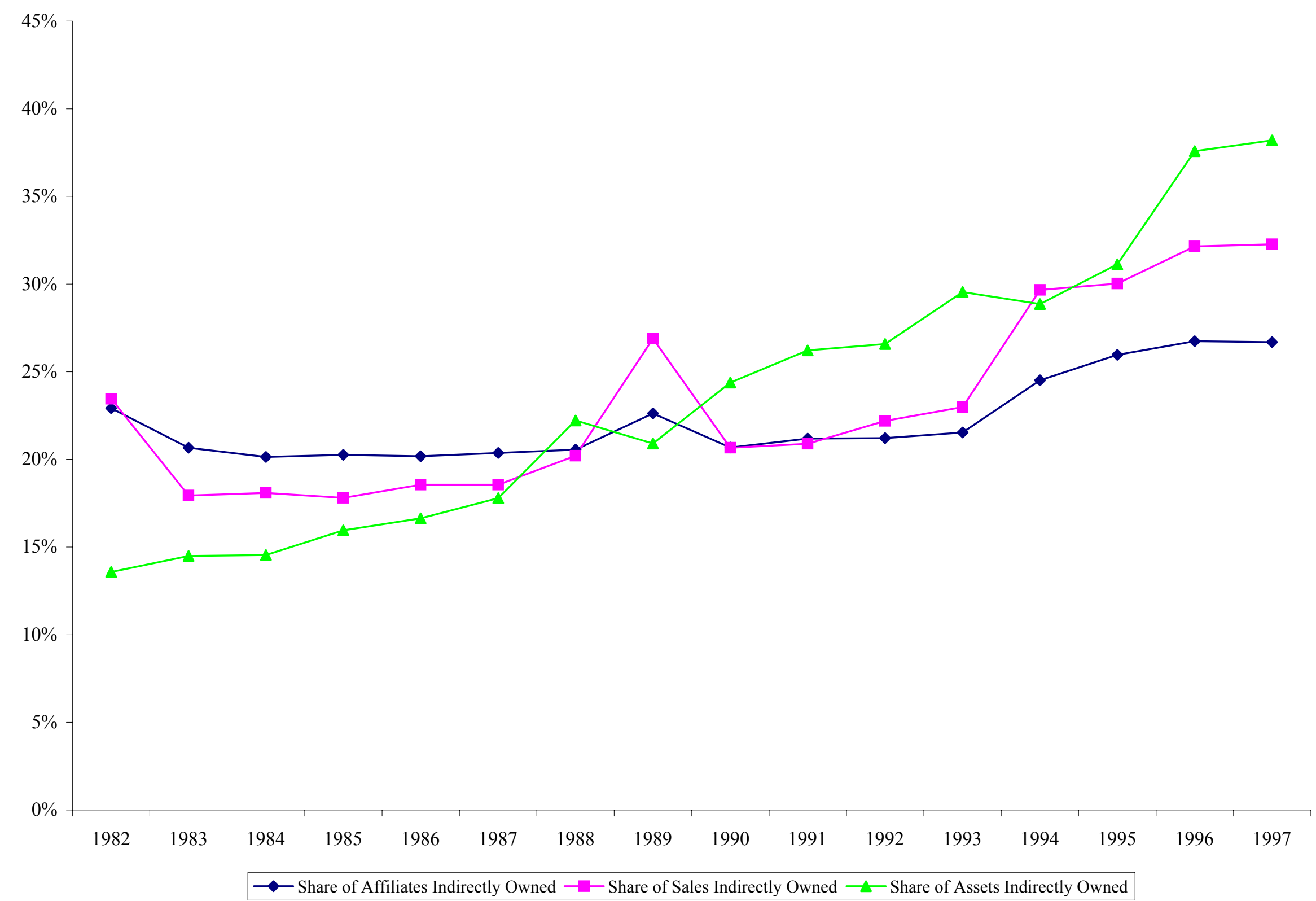

Note: The loci detail ratios of numbers of affiliates with at least some indirect ownership by American parents, and their sales and assets, to comparable figures for all American-owned foreign affiliates from 1982 to 1997. 
Table 1

Descriptive Statistics for Directly Owned and Indirectly Owned Affiliates of U.S. Multinationals in 1982, 1989, 1994 and 1997

Sales

\begin{tabular}{|c|c|c|c|}
\hline \multicolumn{3}{|c|}{ Benchmark Years } & \\
\hline 1982 & 1989 & 1994 & 1997 \\
\hline 58,494 & 67,614 & 77,210 & 152,613 \\
\hline 10,714 & 12,342 & 13,552 & 41,578 \\
\hline 329,562 & 410,611 & 467,115 & 662,659 \\
\hline
\end{tabular}

Some Indirect Ownership

Mean

57,174

82,907

100,573

199,759

Median

11,399

13,369

15,845

43,091

Standard Deviation

288,15

378,982

414,513

707,734

Assets

Complete Direct Ownership

Mean

82,14

9,877

110,522

105,176

13,376

204,979

Median

443,750

12,696

828,816

43,345

Standard Deviation

688,196

940,310

Some Indirect Ownership

Mean

44,351

102,516

133,389

348,088

9,535

15,083

18,338

53,985

Standard Deviation

226,313

535,446

851,340

$2,723,852$

Employees

Complete Direct Ownership

Mean

383

349

351

541

Median

80

65

67

145

Standard Deviation

2,257

1,623

1,632

1,967

Some Indirect Ownership

Mean

312

385

346

505

Median

75

60

69

119

1,354

2,903

1,270

1,821

Notes: This table provides descriptive statistics for the affiliates of U.S. multinationals in 1982, 1989, 1994 and 1997. The three panels of the table present descriptive statistics for sales, assets, and employees, respectively. Within each panel, the top half provides descriptive data for directly owned and the bottom half provides similar data for those affiliates with some indirect ownership. 
Table 2

The Use of Indirect Ownership by Country, 1982, 1989, 1994, and 1997 for U.S. Multinationals

\begin{tabular}{|c|c|c|c|c|c|c|c|c|}
\hline & \multicolumn{6}{|c|}{ Benchmark Years } & \multirow{2}{*}{\multicolumn{2}{|c|}{1997}} \\
\hline & \multicolumn{2}{|c|}{1982} & \multicolumn{2}{|c|}{1989} & \multicolumn{2}{|c|}{1994} & & \\
\hline & $\begin{array}{c}\text { \# of } \\
\text { Affiliates }\end{array}$ & $\begin{array}{c}\text { Share } \\
\text { Indirectly } \\
\text { Owned }\end{array}$ & $\begin{array}{c}\text { \# of } \\
\text { Affiliates }\end{array}$ & $\begin{array}{c}\text { Share } \\
\text { Indirectly } \\
\text { Owned }\end{array}$ & $\begin{array}{c}\text { \# of } \\
\text { Affiliates }\end{array}$ & $\begin{array}{c}\text { Share } \\
\text { Indirectly } \\
\text { Owned }\end{array}$ & $\begin{array}{c}\text { \# of } \\
\text { Affiliates }\end{array}$ & $\begin{array}{c}\text { Share } \\
\text { Indirectly } \\
\text { Owned }\end{array}$ \\
\hline Canada & 2,073 & $13.7 \%$ & 1,984 & $11.9 \%$ & 2,002 & $11.2 \%$ & 1,150 & $12.7 \%$ \\
\hline Argentina & 210 & $15.2 \%$ & 170 & $20.0 \%$ & 238 & $17.6 \%$ & 212 & $21.7 \%$ \\
\hline Bermuda & 356 & $21.9 \%$ & 299 & $17.4 \%$ & 293 & $17.4 \%$ & 198 & $22.7 \%$ \\
\hline Brazil & 603 & $24.5 \%$ & 509 & $28.1 \%$ & 385 & $21.0 \%$ & 321 & $23.1 \%$ \\
\hline$\underline{\text { Mexico }}$ & 704 & $\underline{13.5 \%}$ & 599 & $\underline{10.0 \%}$ & 795 & $\underline{10.9 \%}$ & 405 & $19.3 \%$ \\
\hline Americas & 3,946 & $16.2 \%$ & 3,561 & $14.8 \%$ & 3,713 & $13.1 \%$ & 2,286 & $17.0 \%$ \\
\hline Belgium & 485 & $21.4 \%$ & 549 & $27.9 \%$ & 589 & $30.4 \%$ & 355 & $31.0 \%$ \\
\hline France & 908 & $25.3 \%$ & 1,009 & $29.9 \%$ & 1,169 & $33.0 \%$ & 765 & $33.9 \%$ \\
\hline Germany & 1,041 & $29.1 \%$ & 1,163 & $28.9 \%$ & 1,321 & $32.8 \%$ & 900 & $34.6 \%$ \\
\hline Ireland & 213 & $31.0 \%$ & 250 & $30.8 \%$ & 281 & $31.7 \%$ & 239 & $37.7 \%$ \\
\hline Italy & 541 & $27.4 \%$ & 684 & $28.9 \%$ & 716 & $35.2 \%$ & 448 & $32.4 \%$ \\
\hline Netherlands & 689 & $30.0 \%$ & 827 & $32.6 \%$ & 973 & $30.7 \%$ & 695 & $36.8 \%$ \\
\hline Spain & 355 & $25.9 \%$ & 456 & $30.9 \%$ & 523 & $34.8 \%$ & 327 & $33.9 \%$ \\
\hline Sweden & 204 & $27.5 \%$ & 225 & $27.1 \%$ & 285 & $29.5 \%$ & 177 & $28.8 \%$ \\
\hline Switzerland & 529 & $24.8 \%$ & 514 & $21.2 \%$ & 498 & $24.1 \%$ & 304 & $24.0 \%$ \\
\hline United Kingdom & 1,953 & $29.2 \%$ & 2,195 & $27.1 \%$ & 2,333 & $28.7 \%$ & 1,520 & $31.9 \%$ \\
\hline Europe & 6,918 & $27.6 \%$ & 7,872 & $28.5 \%$ & 8,688 & $31.0 \%$ & 5,730 & $33.0 \%$ \\
\hline Australia & 757 & $21.8 \%$ & 761 & $22.1 \%$ & 826 & $19.7 \%$ & 520 & $25.4 \%$ \\
\hline Hong Kong & 320 & $17.8 \%$ & 451 & $13.3 \%$ & 525 & $14.3 \%$ & 320 & $20.0 \%$ \\
\hline Japan & 701 & $14.0 \%$ & 844 & $19.1 \%$ & 978 & $23.8 \%$ & 581 & $22.5 \%$ \\
\hline Singapore & 238 & $23.5 \%$ & 331 & $20.2 \%$ & 435 & $18.4 \%$ & 276 & $22.8 \%$ \\
\hline China & $\underline{\mathrm{NA}}$ & NA & 64 & $32.8 \%$ & 220 & $\underline{30.9 \%}$ & 238 & $32.4 \%$ \\
\hline Asia and Australia & $\overline{N A}$ & $\overline{N A}$ & 2,451 & $19.5 \%$ & 2,984 & $20.7 \%$ & 1,935 & $24.1 \%$ \\
\hline
\end{tabular}

Note: This table presents numbers of American affiliates, and shares of affiliates with some indirect ownership, for the twenty countries with the most foreign affiliates of U.S. multinational firms in 1997. Countries are grouped by region and data are provided for benchmark years and 1997. 
Table 3

Effective Income Tax Rates by Country, 1982, 1989, 1994, and 1997 for U.S. Multinationals

\begin{tabular}{|c|c|c|c|c|}
\hline \multirow{4}{*}{ Americas } & \multicolumn{3}{|c|}{ Benchmark Years } & \multirow[b]{2}{*}{1997} \\
\hline & \multirow[t]{2}{*}{1982} & \multirow[t]{2}{*}{1989} & \multirow[t]{2}{*}{1994} & \\
\hline & & & & \\
\hline & $46.0 \%$ & $34.7 \%$ & $30.0 \%$ & $31.7 \%$ \\
\hline Argentina & $15.6 \%$ & $15.9 \%$ & $22.0 \%$ & $23.6 \%$ \\
\hline Bermuda & $2.5 \%$ & $3.4 \%$ & $4.6 \%$ & $2.7 \%$ \\
\hline Brazil & $32.7 \%$ & $45.1 \%$ & $23.3 \%$ & $16.6 \%$ \\
\hline Mexico & $28.3 \%$ & $32.9 \%$ & $19.5 \%$ & $28.7 \%$ \\
\hline \multicolumn{5}{|l|}{ Europe } \\
\hline Belgium & $29.9 \%$ & $24.2 \%$ & $19.3 \%$ & $27.4 \%$ \\
\hline France & $44.6 \%$ & $35.8 \%$ & $22.8 \%$ & $29.0 \%$ \\
\hline Germany & $42.2 \%$ & $38.1 \%$ & $31.8 \%$ & $33.7 \%$ \\
\hline Ireland & $3.8 \%$ & $2.3 \%$ & $9.5 \%$ & $9.1 \%$ \\
\hline Italy & $36.5 \%$ & $40.3 \%$ & $33.4 \%$ & $41.0 \%$ \\
\hline Netherlands & $40.2 \%$ & $21.2 \%$ & $24.1 \%$ & $17.2 \%$ \\
\hline Spain & $24.6 \%$ & $23.6 \%$ & $22.6 \%$ & $24.6 \%$ \\
\hline Sweden & $44.1 \%$ & $34.5 \%$ & $19.3 \%$ & $20.6 \%$ \\
\hline Switzerland & $15.9 \%$ & $12.9 \%$ & $6.8 \%$ & $8.8 \%$ \\
\hline United Kingdom & $57.5 \%$ & $29.0 \%$ & $27.8 \%$ & $24.9 \%$ \\
\hline \multicolumn{5}{|c|}{ Asia and Australia } \\
\hline Australia & $39.4 \%$ & $32.8 \%$ & $28.6 \%$ & $24.2 \%$ \\
\hline Hong Kong & $11.5 \%$ & $11.9 \%$ & $10.4 \%$ & $11.5 \%$ \\
\hline Japan & $46.6 \%$ & $50.1 \%$ & $48.9 \%$ & $46.3 \%$ \\
\hline Singapore & $20.4 \%$ & $9.7 \%$ & $8.4 \%$ & $5.6 \%$ \\
\hline China & NA & $23.4 \%$ & $5.3 \%$ & $10.5 \%$ \\
\hline
\end{tabular}

Note: This table provides effective income tax rate measures for U.S. multinational affiliates in the twenty countries with the most affiliates in 1997. Countries are grouped by region and data are provided for benchmark years and 1997. Effective income tax rates are calculated by first identifying that affiliates report positive net income and then taking the ratio of the sum of foreign income taxes to the sum of net income and foreign income taxes for all such affiliates in each country and year. 
Table 4

Countries Through Which U.S. Affiliates are Indirectly Owned, 1997

All Countries

Country

Netherlands

United Kingdom

Germany

France

Switzerland

Canada

Bermuda

Belgium

Italy

Australia

Hong Kong

United Kingdom Islands,

Caribbean

Mexico

Sweden

Panama

Worldwide

\begin{tabular}{c} 
No. of \\
Affiliates \\
\hline
\end{tabular}

652

533

280

199

172

165

140

81

80

76

67

52

49

46

45

3,046

\begin{tabular}{lrrr}
\multicolumn{3}{c}{ Europe } & \\
\cline { 1 - 2 } \multicolumn{1}{c}{ Country } & & $\begin{array}{c}\text { No. of } \\
\text { Affiliates }\end{array}$ & $\begin{array}{c}\text { Share of } \\
\text { Total }\end{array}$ \\
Netherlands & 532 & & $26.2 \%$ \\
United Kingdom & 486 & & 23.9 \\
Germany & 259 & 12.7 \\
France & 190 & 9.3 \\
Switzerland & 121 & 5.9 \\
Italy & 78 & 3.8 \\
Belgium & 76 & 3.7 \\
Canada & 43 & 2.1 \\
Sweden & 40 & 2.0 \\
Bermuda & 34 & 1.7 \\
Luxembourg & 29 & 1.4 \\
& & \\
Ireland & 27 & 1.3 \\
Spain & 22 & 1.1 \\
Panama & 14 & 0.7 \\
Austria & 13 & 0.6 \\
& & \\
All Europe & 2,034 &
\end{tabular}

\footnotetext{
Note: The table presents numbers of indirectly owned foreign affiliates of American companies, by the countries through which these affiliates are indirectly owned, in 1997. The left panel provides data for indirectly owned affiliates around the world and the right panel provides data only for indirectly owned affiliates in Europe. The share of all indirectly owned affiliates worldwide or in Europe is provided in the final column of each panel. This table reports figures only for majority owned affiliates in 1997, and an affiliate is classified as indirectly owned if its American parent has any indirect ownership.
} 
Table 5

Investment and Tax Effects across Regions

Dependent Variable: Log of Total Assets

(1)

Constant

Country Tax Rate

European Dummy

Interaction of European Dummy and Country Tax Rate

Interaction of European Dummy, Country Tax Rate and Time Trend

Asia Dummy

Interaction of Asia Dummy and Country Tax Rate

Latin America Dummy

Interaction of Latin America

Dummy and Country Tax Rate

Year Effects?

Parent Effects?

GNP Controls?

No. of Obs.

R-Squared
(2)

161.6931

(71.3937)

161.0572

(27.6200)

(3)

(4)

(5)

(6)

(7)

(8)

(9)

(10)

(68.8512)

(27.0189)

153.9674

150.5773

(26.9648)

139.1220

(63.8991)

142.3762

(27.4868)

148.5936

(70.4386)

164.8858

(26.7258)

\begin{tabular}{|c|c|c|c|c|c|}
\hline \multirow[t]{4}{*}{$\begin{array}{r}-0.7409 \\
(0.3364)\end{array}$} & $\begin{array}{r}-0.4956 \\
(0.1259)\end{array}$ & $\begin{array}{r}-0.6225 \\
(0.3547)\end{array}$ & $\begin{array}{r}-0.2315 \\
(0.1431)\end{array}$ & $\begin{array}{r}-0.5633 \\
(0.3504)\end{array}$ & $\begin{array}{r}-0.2449 \\
(0.1421)\end{array}$ \\
\hline & & $\begin{array}{r}0.1735 \\
(0.2258)\end{array}$ & $\begin{array}{r}0.3013 \\
(0.0833)\end{array}$ & $\begin{array}{r}0.0571 \\
(0.2268)\end{array}$ & $\begin{array}{r}0.2879 \\
(0.0851)\end{array}$ \\
\hline & & $\begin{array}{r}-0.0720 \\
(0.7172)\end{array}$ & $\begin{array}{r}-0.5380 \\
(0.2593)\end{array}$ & $\begin{array}{r}-0.8227 \\
(0.8597)\end{array}$ & $\begin{array}{r}-0.6635 \\
(0.3333)\end{array}$ \\
\hline & & & & $\begin{array}{r}0.1295 \\
(0.0778)\end{array}$ & $\begin{array}{r}0.0188 \\
(0.0290)\end{array}$ \\
\hline
\end{tabular}

$\begin{array}{rr}0.0137 & 0.0202 \\ (0.2626) & (0.0964) \\ & \\ -0.1306 & -0.1971 \\ (0.7795) & (0.2871)\end{array}$

$0.2249 \quad 0.1197$

$(0.2962) \quad(0.1054)$

$-0.9399 \quad-1.0118$

$(0.7685) \quad(0.3326)$

$\begin{array}{ll}\mathrm{N} & \mathrm{Y} \\ \mathrm{N} & \mathrm{Y} \\ \mathrm{Y} & \mathrm{Y}\end{array}$

$20,346 \quad 20,346$

$0.0108 \quad 0.4502$

$\begin{array}{ll}\mathrm{N} & \mathrm{Y} \\ \mathrm{N} & \mathrm{Y} \\ \mathrm{Y} & \mathrm{Y}\end{array}$

20,346

0.0127

\section{0,346}

0.4520

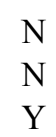

$\begin{array}{ll}\mathrm{N} & \mathrm{Y} \\ \mathrm{N} & \mathrm{Y} \\ \mathrm{Y} & \mathrm{Y}\end{array}$

$20,346 \quad 20,346$

$$
\begin{aligned}
& \mathrm{N} \\
& \mathrm{N} \\
& \mathrm{Y}
\end{aligned}
$$

20,346

0.0127

$$
\begin{aligned}
& \mathrm{Y} \\
& \mathrm{Y} \\
& \mathrm{Y}
\end{aligned}
$$

$$
\begin{aligned}
& \mathrm{N} \\
& \mathrm{N} \\
& \mathrm{Y}
\end{aligned}
$$$$
\begin{aligned}
& \mathrm{Y} \\
& \mathrm{Y} \\
& \mathrm{Y}
\end{aligned}
$$

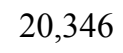

0.4521
20,346

0.0133
0.0062

$(0.1656)$

0.3250

$(0.0881)$

$-0.7418$

$(0.2744)$

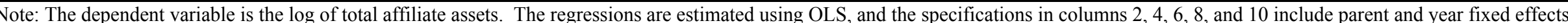

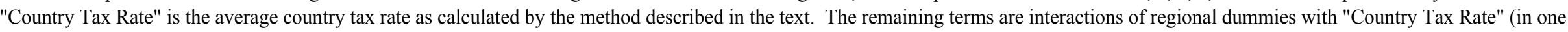

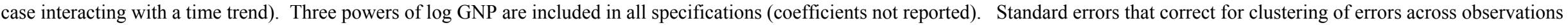
in country/year cells are presented in parentheses. 
Table 6

Profitability and Coordination of Tax Avoidance across Regions

Dependent Variable: Net Income

\begin{tabular}{|c|c|c|c|c|c|c|c|c|c|c|}
\hline & (1) & (2) & (3) & (4) & (5) & (6) & (7) & (8) & (9) & (10) \\
\hline Assets & $\begin{array}{r}0.0702 \\
(0.0056)\end{array}$ & $\begin{array}{r}1.0346 \\
(0.0829)\end{array}$ & $\begin{array}{r}0.0545 \\
(0.0051)\end{array}$ & $\begin{array}{r}1.0273 \\
(0.0799)\end{array}$ & $\begin{array}{r}0.0545 \\
(0.0051)\end{array}$ & $\begin{array}{r}1.0309 \\
(0.0847)\end{array}$ & $\begin{array}{r}0.0515 \\
(0.0053)\end{array}$ & $\begin{array}{r}1.0224 \\
(0.0922)\end{array}$ & $\begin{array}{r}0.0477 \\
(0.0083)\end{array}$ & $\begin{array}{r}1.0182 \\
(0.0898)\end{array}$ \\
\hline $\begin{array}{l}\text { Interaction of Assets and } \\
\text { Country Tax Rate }\end{array}$ & $\begin{array}{r}-0.0680 \\
(0.0157)\end{array}$ & $\begin{array}{r}-0.0895 \\
(0.0123)\end{array}$ & $\begin{array}{r}-0.0161 \\
(0.0158)\end{array}$ & $\begin{array}{r}-0.0556 \\
(0.0114)\end{array}$ & $\begin{array}{r}-0.0161 \\
(0.0158)\end{array}$ & $\begin{array}{r}-0.0526 \\
(0.0114)\end{array}$ & $\begin{array}{r}-0.0176 \\
(0.0194)\end{array}$ & $\begin{array}{r}-0.0731 \\
(0.0166)\end{array}$ & $\begin{array}{r}-0.0078 \\
(0.0212)\end{array}$ & $\begin{array}{r}-0.0501 \\
(0.0163)\end{array}$ \\
\hline $\begin{array}{l}\text { Interaction of European } \\
\text { Dummy and Assets }\end{array}$ & & & $\begin{array}{r}0.0476 \\
(0.0116)\end{array}$ & $\begin{array}{r}0.0236 \\
(0.0085)\end{array}$ & $\begin{array}{r}0.0555 \\
(0.0122)\end{array}$ & $\begin{array}{r}0.0286 \\
(0.0085)\end{array}$ & $\begin{array}{r}0.0506 \\
(0.0117)\end{array}$ & $\begin{array}{r}0.0263 \\
(0.0083)\end{array}$ & $\begin{array}{r}0.0544 \\
(0.0133)\end{array}$ & $\begin{array}{r}0.0289 \\
(0.0104)\end{array}$ \\
\hline $\begin{array}{l}\text { Interaction of European } \\
\text { Dummy and Assets and } \\
\text { Country Tax Rate }\end{array}$ & & & $\begin{array}{r}-0.1681 \\
(0.0357)\end{array}$ & $\begin{array}{r}-0.1154 \\
(0.0246)\end{array}$ & $\begin{array}{r}-0.1273 \\
(0.0340)\end{array}$ & $\begin{array}{r}-0.0802 \\
(0.0261)\end{array}$ & $\begin{array}{r}-0.1666 \\
(0.0375)\end{array}$ & $\begin{array}{r}-0.1007 \\
(0.0247)\end{array}$ & $\begin{array}{r}-0.1764 \\
(0.0384)\end{array}$ & $\begin{array}{r}-0.1208 \\
(0.0273)\end{array}$ \\
\hline $\begin{array}{l}\text { Interaction of European } \\
\text { Dummy and Assets, Country } \\
\text { Tax Rate and Time Trend }\end{array}$ & & & & & $\begin{array}{r}-0.0060 \\
(0.0024)\end{array}$ & $\begin{array}{r}-0.0048 \\
(0.0020)\end{array}$ & & & & \\
\hline $\begin{array}{l}\text { Interaction of Asia Dummy and } \\
\text { Assets }\end{array}$ & & & & & & & $\begin{array}{r}0.0140 \\
(0.0118)\end{array}$ & $\begin{array}{r}0.0131 \\
(0.0086)\end{array}$ & & \\
\hline $\begin{array}{l}\text { Interaction of Asia Dummy, } \\
\text { Assets and Country Tax Rate }\end{array}$ & & & & & & & $\begin{array}{r}-0.0144 \\
(0.0361)\end{array}$ & $\begin{array}{r}0.0148 \\
(0.0255)\end{array}$ & & \\
\hline $\begin{array}{l}\text { Interaction of Latin America } \\
\text { Dummy and Assets }\end{array}$ & & & & & & & & & $\begin{array}{r}0.0062 \\
(0.0108)\end{array}$ & $\begin{array}{r}0.0033 \\
(0.0078)\end{array}$ \\
\hline $\begin{array}{l}\text { Interaction of Latin America } \\
\text { Dummy, Assets and Country } \\
\text { Tax Rate }\end{array}$ & & & & & & & & & $\begin{array}{r}0.0646 \\
(0.0376)\end{array}$ & $\begin{array}{r}0.0612 \\
(0.0298)\end{array}$ \\
\hline $\begin{array}{l}\text { Year Effects? } \\
\text { Industry Effects? }\end{array}$ & $\begin{array}{l}\mathrm{N} \\
\mathrm{N}\end{array}$ & $\begin{array}{l}\mathrm{Y} \\
\mathrm{Y}\end{array}$ & $\begin{array}{l}\mathrm{N} \\
\mathrm{N}\end{array}$ & $\begin{array}{l}\mathrm{Y} \\
\mathrm{Y}\end{array}$ & $\begin{array}{l}\mathrm{N} \\
\mathrm{N}\end{array}$ & $\begin{array}{l}\mathrm{Y} \\
\mathrm{Y}\end{array}$ & $\begin{array}{l}\mathrm{N} \\
\mathrm{N}\end{array}$ & $\begin{array}{l}\mathrm{Y} \\
\mathrm{Y}\end{array}$ & $\begin{array}{l}\mathrm{N} \\
\mathrm{N}\end{array}$ & $\begin{array}{l}\mathrm{Y} \\
\mathrm{Y}\end{array}$ \\
\hline $\begin{array}{l}\text { No. of Obs. } \\
\text { R-Squared }\end{array}$ & $\begin{array}{r}185,813 \\
0.2147\end{array}$ & $\begin{array}{r}185,813 \\
0.3548\end{array}$ & $\begin{array}{r}185,813 \\
0.2231\end{array}$ & $\begin{array}{r}185,813 \\
0.3590\end{array}$ & $\begin{array}{r}185,813 \\
0.2252\end{array}$ & $\begin{array}{r}185,813 \\
0.3598\end{array}$ & $\begin{array}{r}185,813 \\
0.2239\end{array}$ & $\begin{array}{r}185,813 \\
0.3611\end{array}$ & $\begin{array}{r}185,813 \\
0.2257\end{array}$ & $\begin{array}{r}185,813 \\
0.3606\end{array}$ \\
\hline
\end{tabular}

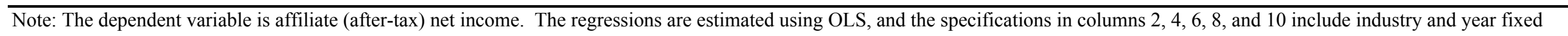

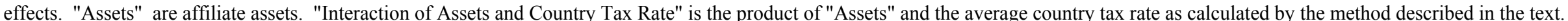

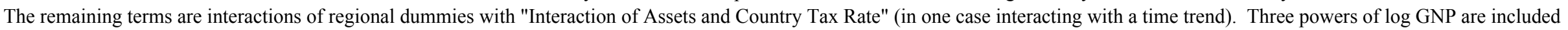
in all specifications (coefficients not reported). Standard errors that correct for clustering of errors across observations in country/year cells are presented in parentheses. 
Table 7

Indirect Ownership, Investment and Tax Effects

Dependent Variable: Log of Total Assets

\begin{tabular}{|c|c|c|c|c|}
\hline & (1) & (2) & (3) & (4) \\
\hline Constant & $\begin{array}{r}160.4116 \\
(70.5339)\end{array}$ & $\begin{array}{l}160.0111 \\
(27.3701)\end{array}$ & $\begin{array}{r}145.3849 \\
(67.7367)\end{array}$ & $\begin{array}{l}148.6309 \\
(26.7782)\end{array}$ \\
\hline Country Tax Rate & $\begin{array}{r}-0.4944 \\
(0.3384)\end{array}$ & $\begin{array}{l}-0.2591 \\
(0.1358)\end{array}$ & $\begin{array}{l}-0.3969 \\
(0.3570)\end{array}$ & $\begin{array}{r}-0.0400 \\
(0.1560)\end{array}$ \\
\hline European Dummy & & & $\begin{array}{r}0.1759 \\
(0.2256)\end{array}$ & $\begin{array}{r}0.3065 \\
(0.0860)\end{array}$ \\
\hline $\begin{array}{l}\text { Interaction of European Dummy and } \\
\text { Country Tax Rate }\end{array}$ & & & $\begin{array}{l}-0.0506 \\
(0.7068)\end{array}$ & $\begin{array}{l}-0.4447 \\
(0.2650)\end{array}$ \\
\hline Indirect Ownership Dummy & $\begin{array}{r}0.5514 \\
(0.1009)\end{array}$ & $\begin{array}{r}0.3420 \\
(0.0766)\end{array}$ & $\begin{array}{r}0.6602 \\
(0.1369)\end{array}$ & $\begin{array}{r}0.4062 \\
(0.1026)\end{array}$ \\
\hline $\begin{array}{l}\text { Interaction of Indirect Ownership } \\
\text { Dummy and European Dummy }\end{array}$ & & & $\begin{array}{l}-0.2235 \\
(0.1773)\end{array}$ & $\begin{array}{l}-0.1541 \\
(0.1364)\end{array}$ \\
\hline $\begin{array}{l}\text { Interaction of Indirect Ownership } \\
\text { Dummy and Country Tax Rate }\end{array}$ & $\begin{array}{r}-1.0373 \\
(0.3506)\end{array}$ & $\begin{array}{r}-0.9376 \\
(0.2513)\end{array}$ & $\begin{array}{l}-1.1722 \\
(0.5012)\end{array}$ & $\begin{array}{l}-0.9225 \\
(0.3792)\end{array}$ \\
\hline $\begin{array}{l}\text { Interaction of European Dummy, } \\
\text { Indirect Ownership Dummy, and } \\
\text { Country Tax Rate }\end{array}$ & & & $\begin{array}{r}0.2842 \\
(0.6271)\end{array}$ & $\begin{array}{r}0.0305 \\
(0.4836)\end{array}$ \\
\hline Year Effects? & $\mathrm{N}$ & $\mathrm{Y}$ & $\mathrm{N}$ & Y \\
\hline Parent Effects? & $\mathrm{N}$ & $\mathrm{Y}$ & $\mathrm{N}$ & Y \\
\hline GNP Controls? & $\mathrm{Y}$ & Y & $\mathrm{Y}$ & Y \\
\hline $\begin{array}{l}\text { No. of Obs. } \\
\text { R-Squared }\end{array}$ & $\begin{array}{c}20,346 \\
0.0172\end{array}$ & $\begin{array}{c}20,346 \\
0.4515\end{array}$ & $\begin{array}{c}20,346 \\
0.0189\end{array}$ & $\begin{array}{c}20,346 \\
0.4534\end{array}$ \\
\hline
\end{tabular}

Note: The dependent variable is the log of total affiliate assets. The regressions are estimated using OLS, and the specifications in columns 2 and 4 include parent and year fixed effects. "Country Tax Rate" is the average country tax rate calculated by the method described in the text. The remaining terms are interactions of regional dummies, a dummy variable indicating indirect ownership and "Country Tax Rate." Indirect ownership dummies equal one for affiliates with some indirect ownership by their American parent. Three powers of log GNP are included in all specifications (coefficients not reported). Standard errors that correct for clustering of errors across observations in country/year cells are presented in parentheses. 
Table 8

Indirect Ownership, Profitability and Coordination of Tax Avoidance

Dependent Variable: Net Income

\begin{tabular}{|c|c|c|c|c|}
\hline & (1) & (2) & (3) & (4) \\
\hline Assets & $\begin{array}{r}0.0628 \\
(0.0061)\end{array}$ & $\begin{array}{r}1.0268 \\
(0.0963)\end{array}$ & $\begin{array}{r}0.0516 \\
(0.0061)\end{array}$ & $\begin{array}{r}1.0230 \\
(0.0819)\end{array}$ \\
\hline $\begin{array}{l}\text { Interaction of Assets and Country Tax } \\
\text { Rate }\end{array}$ & $\begin{array}{r}-0.0469 \\
(0.0168)\end{array}$ & $\begin{array}{r}-0.0708 \\
(0.0133)\end{array}$ & $\begin{array}{r}-0.0065 \\
(0.0180)\end{array}$ & $\begin{array}{r}-0.0436 \\
(0.0123)\end{array}$ \\
\hline $\begin{array}{l}\text { Interaction of European Dummy and } \\
\text { Assets }\end{array}$ & & & $\begin{array}{r}0.0361 \\
(0.0136)\end{array}$ & $\begin{array}{r}0.0122 \\
(0.0099)\end{array}$ \\
\hline $\begin{array}{l}\text { Interaction of European Dummy and } \\
\text { Assets and Country Tax Rate }\end{array}$ & & & $\begin{array}{r}-0.1323 \\
(0.0397)\end{array}$ & $\begin{array}{r}-0.0905 \\
(0.0282)\end{array}$ \\
\hline $\begin{array}{l}\text { Interaction of Indirect Ownership Dummy } \\
\text { and Assets }\end{array}$ & $\begin{array}{r}0.0266 \\
(0.0082)\end{array}$ & $\begin{array}{r}0.0310 \\
(0.0079)\end{array}$ & $\begin{array}{r}0.0116 \\
(0.0093)\end{array}$ & $\begin{array}{r}0.0201 \\
(0.0086)\end{array}$ \\
\hline $\begin{array}{l}\text { Interaction of Indirect Ownership Dummy, } \\
\text { Assets and Country Tax Rate }\end{array}$ & $\begin{array}{r}-0.0809 \\
(0.0253)\end{array}$ & $\begin{array}{r}-0.0704 \\
(0.0242)\end{array}$ & $\begin{array}{r}-0.0393 \\
(0.0258)\end{array}$ & $\begin{array}{r}-0.0474 \\
(0.0241)\end{array}$ \\
\hline $\begin{array}{l}\text { Interaction of European Dummy, Indirect } \\
\text { Ownership Dummy, and Assets }\end{array}$ & & & $\begin{array}{r}0.0392 \\
(0.0190)\end{array}$ & $\begin{array}{r}0.0244 \\
(0.0178)\end{array}$ \\
\hline $\begin{array}{l}\text { Interaction of European Dummy, Indirect } \\
\text { Ownership Dummy, Assets and Country } \\
\text { Tax Rate }\end{array}$ & & & $\begin{array}{l}-0.1385 \\
(0.0625)\end{array}$ & $\begin{array}{r}-0.0593 \\
(0.0569)\end{array}$ \\
\hline $\begin{array}{l}\text { Year Effects? } \\
\text { Industry Effects? }\end{array}$ & $\begin{array}{l}\mathrm{N} \\
\mathrm{N}\end{array}$ & $\begin{array}{l}\mathrm{Y} \\
\mathrm{Y}\end{array}$ & $\begin{array}{l}\mathrm{N} \\
\mathrm{N}\end{array}$ & $\begin{array}{l}\mathrm{Y} \\
\mathrm{Y}\end{array}$ \\
\hline $\begin{array}{l}\text { No. of Obs. } \\
\text { R-Squared }\end{array}$ & $\begin{array}{r}185,813 \\
0.2169\end{array}$ & $\begin{array}{r}185,813 \\
0.3582\end{array}$ & $\begin{array}{r}185,813 \\
0.2260\end{array}$ & $\begin{array}{r}185,813 \\
0.3630\end{array}$ \\
\hline \multicolumn{5}{|c|}{$\begin{array}{l}\text { Note: The dependent variable is affiliate (after-tax) net income. The regressions are estimated using OLS, and the specifications in } \\
\text { columns } 2 \text { and } 4 \text { include industry and year fixed effects. "Assets" are affiliate assets. "Interaction of Assets and Country Tax } \\
\text { Rate" is the product of "Assets" and the average country tax rate calculated by the method described in the text. The remaining } \\
\text { terms are interactions of regional dummies, a dummy variable indicating indirect ownership and "Interaction of Assets and } \\
\text { Country Tax Rate." Indirect ownership dummies equal one for affiliates with some indirect ownership by their American parents. } \\
\text { Three powers of log GNP are included in all specifications (coefficients not reported). Standard errors that correct for clustering } \\
\text { of errors across observations in country/year cells are presented in parentheses. }\end{array}$} \\
\hline
\end{tabular}

